\title{
Laboratory analyses of cyanobacteria and water chemistry
}

\section{Judit Padisák, Ingrid Chorus, Martin Welker, Blahoslav Maršálek and Rainer Kurmayer}

\section{CONTENTS}

$\begin{array}{ll}\text { Introduction } & 690\end{array}$

13.1 Handling and storage of water samples 691

$\begin{array}{ll}13.2 & \text { Identification of cyanobacteria }\end{array}$

$\begin{array}{ll}\text { 13.3 Quantification of cyanobacteria } & 693\end{array}$

13.3.1 Counting cyanobacterial cells 694

13.3.1.1 Sample concentration by sedimentation or centrifugation 694

13.3.1.2 Quantification of cyanobacteria using an inverted microscope 698

13.3.1.3 Quantification of cyanobacteria using a standard microscope $\quad 702$

13.3.2 Estimation of cyanobacterial biomass by microscopy 703 13.3.1.4 Cyanobacterial counts and cell volumes 703

13.4 Estimation of phytoplankton biomass using chlorophyll-a analysis

13.5 Phytoplankton and cyanobacteria quantification by fluorescence analysis

708

13.5.1 Recent advances and future direction in the phytoplankton and cyanobacteria quantification by fluorescence analysis

13.6 Monitoring toxigenic cyanobacteria by molecular methods $\quad 714$

13.6.1 Sampling and nucleic acid extraction 718

13.6.2 Polymerase chain reaction (PCR) methodology 720

13.6.3 Detection of toxigenic cyanobacteria 720

13.6.4 Estimates of cyanobacterial biomass by molecular approaches 722

13.6.5 Set up of PCR assays $\quad 723$

13.6.6 Limits of PCR assays $\quad 724$

13.6.7 Sequencing of PCR products 725

13.6.8 Application of PCR-based methods in monitoring $\quad 725$ 
13.6.9 Identifying toxigenic cyanobacteria using high-throughput sequencing

13.7 Determination of nutrient concentrations 728

$\begin{array}{ll}\text { 13.7.1 Analysis of phosphorus } & 729\end{array}$

13.7.2 Analysis of nitrate $\quad 729$

13.7.3 Analysis of ammonium $\quad 730$

13.7.4 On-site analysis techniques for nutrients $\quad 730$

References

\section{INTRODUCTION}

Identification and quantification of cyanobacteria in water resources is a basic component of cyanotoxin monitoring programmes to effectively allow early alerts of the type of toxins to expect as well as of bloom development. Further, data on concentrations of nutrients, that is, phosphorus and nitrogen, are valuable for assessing the potential for cyanobacteria to develop blooms (Chapter 4). Information on turbidity, waterbody mixing and flow rate supports this assessment. Methods for nutrient analysis have been extensively reviewed and internationally harmonised by the International Organization for Standardization (ISO). In contrast, approaches to identify and quantify cyanobacteria are very variable and can be undertaken at different levels of sophistication. Rapid and simple methods can be employed to analyse the composition of a sample at the taxonomic level of cyanobacterial genera rather than species. This is often sufficient for a preliminary assessment of potential hazard as well as for initial management decisions. Further investigation may be necessary in order to quantify cyanobacteria, for example, to determine whether they are present above a threshold biomass level. Quantitative counting methods can give useful estimates of cell numbers and biovolumes with a counting effort of less than one hour per sample and sometimes within minutes. Bulk methods such as biomass estimation by chlorophyll- $a$ analysis or fluorimetric methods can be very time-effective with only moderate equipment demands. More detailed taxonomic resolution and biomass analysis is necessary to predict cyanobacterial bloom development. Prediction of toxin production carries uncertainties since the dominant species in multispecific cyanobacterial blooms are not necessarily the toxin producers. Distinction between these approaches is important because management must decide how available staff hours are most effectively allocated. In many cases, the priority is likely to be the evaluation of a larger number of samples at a lower level of precision and taxonomic detail.

The choice of methods further requires informed consideration of sources of variability and error at each stage of the monitoring process, particularly for sampling (see Chapter 12). Waterbodies with substantial temporal and spatial variation of cyanobacterial cell density may show variability of orders of magnitude in cyanobacterial biomass between samples taken 
within a few hours or within short distances. A highly accurate determination of biomass from singular weekly samples may not be adequate for the assessment of population size, while more useful information can be gained by investing the same effort into a less accurate evaluation of a larger number of samples, either multiple samples per date or samples taken at a higher frequency. Efficiency can further be optimised by regular interlaboratory calibrations of methods and their quality control as well as through testing the emerging new rapid molecular methods against the results of those obtained with accurate established methods.

This chapter describes methods for cyanobacterial identification and quantification at different levels of accuracy. Further, for determination of the key nutrients $\mathrm{P}$ and $\mathrm{N}$, which control cyanobacterial biomass and species composition, it gives a brief overview of the ISO methods and guidance on how to assess key hydrophysical conditions.

\section{I HANDLING AND STORAGE OF WATER SAMPLES}

Decisions on the type of analyses required should be made prior to sample collection (see Chapter 12). However, this is not always possible, particularly when a routine monitoring programme is not in place. Samples may therefore require immediate evaluation on arrival in the laboratory to determine if pretreatment is needed prior to appropriate sample storage.

Samples that have been taken for microscopic counting should ideally be preserved with Lugol's iodine solution at the time of collection (section 12.6). These samples will be relatively stable and no special storage conditions are required, other than protection from extreme temperatures and light, for example, in a nontransparent box at room temperature, although storage at $4-6^{\circ} \mathrm{C}$ is preferred. However, samples should be examined and counted as soon as possible because some types of phytoplankton are sensitive to storage (Hawkins et al., 2005) and Lugol's iodine solution is chemically reduced by organic matter in the sample over extended storage periods (usually within months, but faster in very dense samples), visible by fading of the brownish colour of the Lugol's iodine solution. Therefore, a periodical visual check for loss of colour is recommended and add fresh Lugol's solution if decoloration becomes apparent.

Unpreserved samples for quantitative microscopic analysis require immediate attention in the laboratory either by the addition of preservative (e.g., Lugol's solution) or by following instructions of alternative quantification methods which do not use preserved cells. Where unpreserved samples cannot be analysed immediately, they should be stored in the dark at a temperature close to ambient field temperatures. Unpreserved samples are preferable for species identification because some characteristics cannot be recognised in preserved samples. For example, filaments of Aphanizomenon flosaquae aggregate to characteristic bundles, but preservatives tend to disintegrate 
bundles, and the isolated filaments are more difficult to distinguish from other species and genera. While samples for quantification must be preserved immediately, to samples for identification generally no preservative is added and these should be analysed within approximately $24 \mathrm{~h}$ because quantitative changes are less important.

Samples for chlorophyll-a, dissolved phosphorus, nitrate, ammonium and molecular analyses should be filtered as soon as possible. Storage for a few hours in the dark in glass bottles is usually acceptable if temperatures do not exceed $20^{\circ} \mathrm{C}$. Filtration at the sampling site is recommended, particularly in warm climates, or filtration should occur immediately upon arrival in the laboratory. Filtered samples for nutrient analysis may be stored at $4-6{ }^{\circ} \mathrm{C}$ for a few hours prior to analysis, or frozen at $-20^{\circ} \mathrm{C}$ for several days, or at $-80^{\circ} \mathrm{C}$ for several weeks. If extended storage (weeks to months) of loaded filters is intended, the filters are preferably freeze-dried and stored at $-20^{\circ} \mathrm{C}$ to minimise the degradation of chlorophyll- $a$, for example. Samples collected for RNA analysis or sequencing require immediate filtration and placement on dry ice until transferred to low-temperature freezer.

\subsection{IDENTIFICATION OF CYANOBACTERIA}

Microscopic examination of a bloom sample is very useful even when accurate counting is not being carried out. The information on cyanobacterial taxa in a sample can provide an instant alert that cyanotoxins may be present. This information can trigger the choice of the method for toxin analysis (see Chapter 14). Most cyanobacteria can be readily distinguished from other phytoplankton and particles under the microscope at a magnification of 100-400 times (see also Chapter 3).

However, organisms identified as belonging to a single species may be highly variable with respect to toxin content (see Chapter 4). Environmental populations of particular species generally consist of multiple genotypes that are not distinguishable based on morphological characteristics but with varying toxin contents. For the commonly occurring genera Microcystis, Planktothrix, Aphanizomenon, Raphidiopsis (Cylindrospermopsis) and Dolichospermum (Anabaena), identification on the genus level is often sufficient to allow a prediction on the presence of particular types of toxins (Chapters 2-4). Moreover, microscopic analysis often does not allow the differentiation of individual species for several reasons, such as uncertainties in the taxonomic scheme, absence of characteristic and stable morphological features or lack of experience. Preferably, identification results are then given at the genus level, for example, Aphanizomenon spp. (for "species pluralis": multiple species).

For establishing cyanobacterial identification in a laboratory, consultation with experts on cyanobacterial identification is helpful. Training courses for beginners should focus on the genera and species relevant in the 
region to be monitored. Experts can assist in initially deriving a list of these taxa and the criteria for their identification, and later by evaluating micrographs of the typical cyanobacteria, provided microscopes equipped with a camera are available. In the course of further monitoring, experienced experts should be consulted periodically for quality control and for updating such a list. Last but not the least, continuity of individual staff, that is, long-term responsibility for identification and enumeration, is highly valuable to facilitate identification and to allow the recognition of shifts in taxonomic composition.

Key morphological characteristics of cyanobacteria are described in Chapter 3, and Table 13.1 shows identification keys assisting in the determination of major cyanobacterial groups, genera and species.

\section{I3.3 QUANTIFICATION OF CYANOBACTERIA}

Rapid methods for frequent monitoring of large numbers of waterbodies or sampling sites have been developed in some countries. These methods cannot be readily standardised and evaluated internationally, but can be adapted to regional or local conditions. Deciding on the appropriate classification of units to count depends upon variations such as whether prevalent taxa are filamentous, colony-forming or occur as single cells, and whether populations are very diverse or largely monospecific.

Cyanobacterial biomass can also be determined using indirect methods, the most common being the quantification of chlorophyll- $a$. The established

Table 13.I Compilation of taxonomic keys for various taxa of cyanobacteria

\begin{tabular}{ll}
\hline Reference & \multicolumn{1}{c}{ Covered taxa } \\
\hline Anagnostidis \& Komárek (1985) & Major groups \\
Komárek \& Anagnostidis (1986) & "Chroococcales" \\
Komárek \& Anagnostidis (2008) & \\
Anagnostidis \& Komárek (1988) & "Oscillatoriales" \\
Komárek \& Anagnostidis (2007) & "Nostocales" \\
Komárek \& Anagnostidis (1989) & "Stigonematales" \\
Anagnostidis \& Komárek (1990) & Heterocytous genera \\
Komárek (20I3) & Microcystis in Japan \\
Komárek (I99I) & Picocyanobacteria \\
Komárek (I996) & Planktonic "Oscillatoreales" \\
Komárek (2003) & Nostocaceae \\
Komárek (20I0) & African “Oscillatoreales" \\
Komárek \& Cronberg (200I) & and "Chroococcales" \\
Komárek \& Zapomělová (2007) & Anabaena/Dolichospermum \\
Kaštovský et al. (20I0) & Invasive cyanobacteria \\
\hline
\end{tabular}


methods (see section 13.5) are rapid and simple but also quantify chlorophyll- $a$ from other phytoplankton; hence, it is best used when cyanobacteria are the main or dominant organisms present. Alternatively, submersible multiprobes measuring in vivo chlorophyll- $a(\mathrm{Chl}-a)$ fluorescence together with that of the pigment specific for cyanobacteria, that is, phycocyanin (PC), are increasingly used (e.g., Ziegmann et al., 2010; McQuaid et al., 2011; Zamyadi et al., 2012; Brentrup et al., 2016). Care should be taken to calibrate fluorimeters (by determining biovolume in selected samples; see section 13.3.2) since otherwise phycoerythrin-rich species might be missed (Selmeczy et al., 2016).

Approaches to monitoring cyanobacterial blooms are reviewed in Srivastava et al. (2013). The procedures and techniques described in the following can be considered as classical approaches. Techniques supported by digital image analysis and computation are emerging and may facilitate the determination of cyanobacterial or, more general, plankton biomass in future (Benfield et al., 2007; Saccà, 2016; Zohary et al., 2016). Automated methods are not yet widely applied for planktological studies and monitoring due to the complexity of the matter. A certain error in quantitative data on plankton biomass has to be accepted with any method (Saccà, 2017), although this error can be reduced by intercalibration exercises between laboratories and operators (Rott, 1981). Molecular methods can also be employed to quantitatively estimate total cyanobacterial biomass and toxigenic potential (see section 13.6).

\subsection{Counting cyanobacterial cells}

Microscopic counting of cyanobacterial cells, filaments or colonies has the advantage of directly assessing the abundance of potentially toxic taxa. Little equipment in addition to a microscope is required. The method may be rather time-consuming, ranging from a few minutes to several hours per sample, depending upon the accuracy required and the number of species to be differentiated. Further, counting time depends to a large degree on personal experience, and therefore, staff continuity is highly desired (Vuorio et al., 2007).

The following begins by outlining precise and widely accepted counting procedures which are more time-consuming and require a moderate level of expertise, but serve as a benchmark to assess the performance of simplified methods which can be developed to suit specific requirements of a given sampling programme. More details can be found, for example, in Olenina et al. (2006) and Karlson et al. (2010).

\subsection{I.I Sample concentration by sedimentation or centrifugation}

Direct counting of preserved cells is typically carried out by Utermöhl's counting technique using a counting chamber and inverted microscope 
(Utermöhl, 1958; CEN, 2006). This method is well suited for the assessment of a large variation in cell morphologies and is widely accepted as reliable. Counting chambers and sedimentation tubes are commercially available or can be built in-house (see Figure 13.1). The most commonly used chambers have a diameter of $2.5 \mathrm{~cm}$ and a height of $0.5 \mathrm{~cm}$ and can be fitted on the stage of an inverted microscope. If larger volumes of water need to be analysed, as is the case when cell density is low, a sedimentation tube can be used to increase the volume. The water volume used for an individual counting depends on density of cells, counting technique (fields or transects, see below) and microscopic magnification. If cell densities were high like in bloom samples, even a few millilitres could contain too many cells for accurate counting, and sample dilution is needed. Optimally, 10-30 items (cells, colonies, filaments) are present in an individual counting field. If less, search for cells in the view field consumes time, and if more, the investigator may get confused by the density and individual cells obscure each other, thus decreasing counting accuracy.

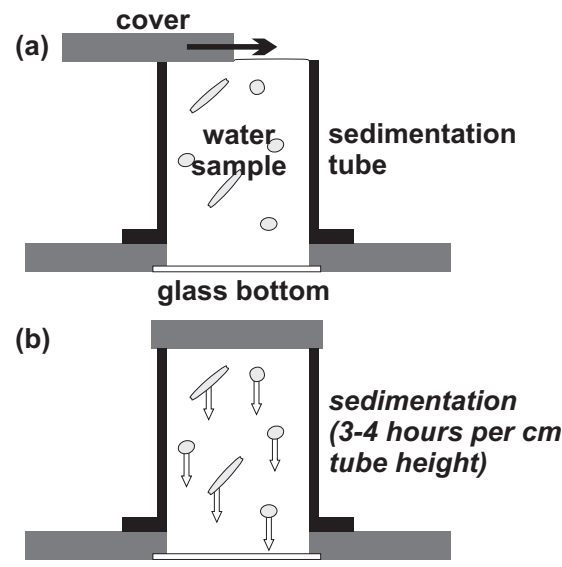

(c)

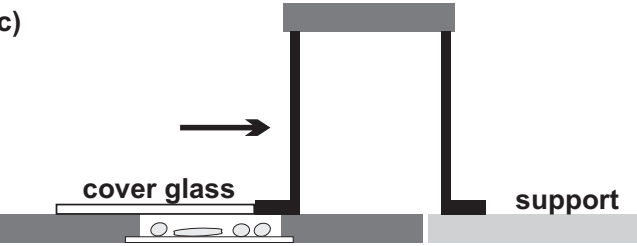

Figure 13.I Preparation of samples in a sediment chamber for counting plankton with an inverted microscope according to Utermöhl (1958). (a) The sedimentation cylinder is placed on the microscope slide and filled completely with the water sample; a cover is slid on the cylinder. (b) The plankton in the sample fixed with Lugol's solution is allowed to sediment. (c) The sedimentation tube is pushed onto a support with a cover glass; the sample is ready for the counting procedure. 
Equipment

- Inverted microscope with 100-, 400- and preferably 1000-fold magnification

- Counting chamber with sedimentation tubes of variable lengths, that is, variable volumes

- Cyanobacterial identification keys and images

- Samples preserved in Lugol's iodine solution (see section 11.3.1)

\section{Procedure}

1. Allow the sample to equilibrate to room temperature. If cold samples are placed directly in the counting chamber, gas bubbles develop disturbing sedimentation and interfere with visibility.

2. Gently invert the bottle containing the sample several times to ensure homogenous mixing.

3. Fill the sample into the sedimentation tube placed on the counting chamber.

4. Place the counting chamber on a stable horizontal surface at dark place with stable temperature.

5. Allow the sample to settle. Sedimentation time varies depending on the height of the sedimentation tube. Allow at least $3-4 \mathrm{~h} / \mathrm{cm}$ height of liquid for samples preserved with Lugol's iodine solution. For samples preserved with neutralised formalin, double the time allowed for sedimentation. Buoyant cells may not settle and require the disruption of the gas vacuoles (see below). However, this problem is frequently overcome by several days of storage with Lugol's solution, through uptake of iodine into the cells.

6. Phytoplankton density can now be determined by counting either the total number of organisms visible in the chamber or subsections (transects, fields) as shown in Figure 13.2.

If an inverted microscope is not available and samples with low cyanobacterial density need to be counted, other techniques may be applied in order to concentrate samples sufficiently, most simply by sedimentation in a glass cylinder and careful removal of the supernatant. However, sedimentation in a glass cylinder or centrifugation generally yields less accurate counting results compared to the sedimentation/counting chambers described above and the latter should be preference whenever available.

\section{Equipment}

- Glass measuring cylinder, $100 \mathrm{~mL}$

- Glass pipette with pipette bulb or filler

- Standard laboratory microscope with $10 \times$ and $40 \times$ objectives

- Sample preserved in Lugol's iodine solution (section 11.3.1) 


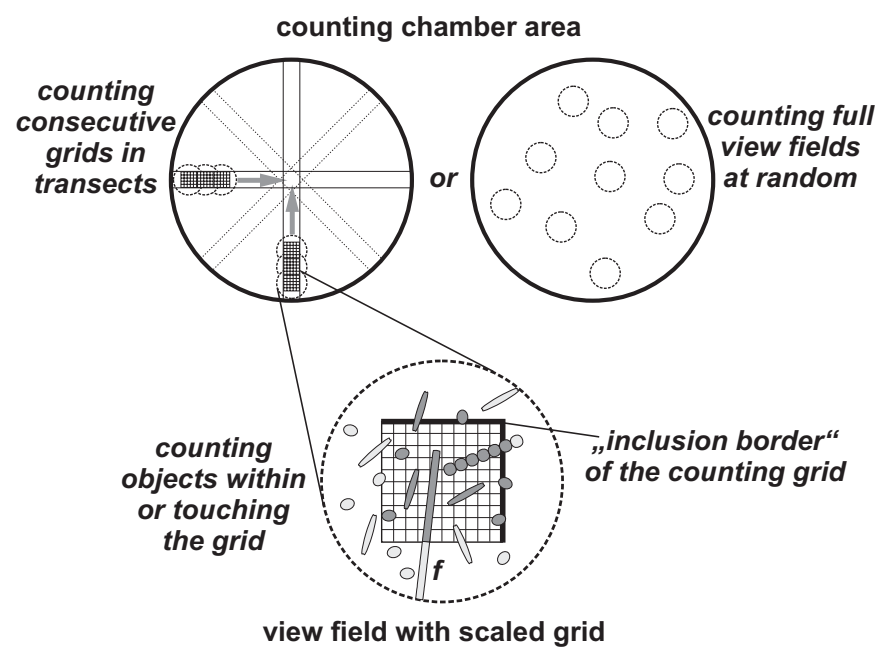

Figure 13.2 Quantitative enumeration of cyanobacterial and plankton cells with Utermöhl technique. Cell counting is done either in multiple consecutive counting grids in the view field following the chamber's transects or in full view fields that are randomly selected. In individual counting grids, two borders are defined as inclusion border. All cells touching these borders are included (dark grey), irrespective of the share of the cell lying within the grid. The opposite borders are defined as exclusion borders with all cells touching these lines to be excluded (light grey). For filaments in which individual cells cannot be distinguished (f), only the share of the filament lying within the grid is measured and counted (dark grey); individual filaments may extend over multiple counting grids or view fields. The grid is moved forward to the next position for the grid's width.

\section{Procedure}

1. Allow the sample to equilibrate to room temperature.

2. Gently invert the bottle containing the sample several times to ensure homogeneous mixing.

3. Fill $100 \mathrm{~mL}$ of the sample into the measuring cylinder.

4. Allow the sample to settle for an appropriate time (see above).

5. Using the glass pipette, carefully remove the supernatant, leaving only the last $5 \mathrm{~mL}$ undisturbed.

6. The sample has now been concentrated by a factor of 20 and can be counted using a counting chamber (e.g., Sedgewick-Rafter or haemocytometer).

Alternatively to sedimentation, centrifugation can offer a rapid and convenient method of concentrating a sample (Ballantine, 1953). Fixation with Lugol's iodine solution enhances the sedimentation. However, buoyant cells may still be difficult to pellet and may require the disruption of vacuoles 
prior to centrifugation (see below). Once concentrated, a known volume can be quantified using a counting chamber or by counting a defined volume using a micropipette to place a drop on a microscope slide. Observation and counting can be done with a standard microscope.

\section{Equipment}

- Centrifuge

- Centrifuge tube, $10-20 \mathrm{~mL}$

- Syringe or bottle with cork, or plastic bottle with screw cap

- Standard laboratory microscope with $10 \times$ and $40 \times$ objectives

\section{Reagents}

- Aluminium potassium sulphate, $1.0 \mathrm{~g}$ AlK $\left(\mathrm{SO}_{4}\right)_{2} \cdot 12 \mathrm{H}_{2} \mathrm{O}$ in $100 \mathrm{~mL}$ distilled water

\section{Procedure}

1. Place $10-20 \mathrm{~mL}$ of sample in a centrifuge tube, seal with cap and centrifuge at a minimum of $500 \times \mathrm{g}$ for $15 \mathrm{~min}$.

2. If pelleting needs to be enhanced, add $0.05 \mathrm{~mL}$ of aluminium potassium sulphate solution per $10 \mathrm{~mL}$ of sample. Mix and centrifuge as described.

3. If pelleting of buoyant cells wasn't possible, try one of the following:

i. Fill sample in a plastic syringe, ensure the end is tightly sealed, then apply pressure to the plunger.

ii. Fill sample in a bottle with a tightly fitting cork, then bang the cork suddenly.

iii. Fill sample in a well-sealed plastic bottle and drop it sharply onto a hard surface.

Once subjected to this pressure shock, the gas vesicles should have been disrupted and cells should pellet when centrifuged.

4. After centrifugation, carefully remove the supernatant and resuspend the pellet in a small known volume (e.g., $0.5 \mathrm{~mL}$ ).

5. Samples concentrated by centrifugation can be counted using a counting grid or haemocytometer.

\subsubsection{Quantification of cyanobacteria using an inverted microscope}

A prerequisite to the counting of cyanobacteria (phytoplankton in general) is the definition of the units to be counted, that is, individual cells, filaments or colonies. Globally, the accuracy of quantitative determination depends on the number of counted objects (Rott et al., 2007), and the relative error is approximately indirectly proportional to the square root of the number of counted objects (see below for more details). 
The majority of bloom-forming, planktonic cyanobacteria form filaments (e.g., Aphanizomenon spp., Dolichospermum spp., Planktothrix spp.) or colonies (e.g., Microcystis spp., Merismopedia spp.) that consist of large numbers of cells which are often difficult to be counted individually. Both filaments and colonies can differ greatly in the number of cells per filament or colony, respectively. Hence, results given as number of colonies or filaments, respectively, per volume of sample do not provide a reliable estimate of the density of cyanobacterial cells or biomass in the sample (Alcántara et al., 2018).

Therefore, disintegration of colonies and subsequent counting of individual cells is preferable to counting colonies and estimating colony size (Box, 1981). Disintegration of colonies sometimes occurs spontaneously several days after fixation with Lugol's iodine solution. For more stable colonies, it can be achieved by heating at $80-90^{\circ} \mathrm{C}$ for $15 \mathrm{~min}$, paralleled by intensive mixing, or gentle ultrasonication may also help. These methods often separate cells very effectively, and even where colonies are not totally broken down into single cells, the colony size may be reduced sufficiently to allow individual cells to be counted. If these approaches failed, the volume of individual colonies could be determined as an estimate of cell density. If colonies were relatively uniform in size, the average number of cells per colony may be determined and used to transform colony numbers to cell numbers (Hötzel \& Croome, 1999). The use of published values for numbers per colony is not recommended because the size of colonies varies greatly.

For filamentous species, a good estimate of cell numbers is calculated from the number of filaments multiplied by the average number of cells per filament. For the latter, the cells per filament are counted for the first 30 filaments encountered and then averaged. A caveat is that cell boundaries may be poorly visible in the microscope or that the average number of cells per filament is very variable, or both. In this case, it may be preferable to measure the length of a number of filaments to compute the average filament length to be used for calculations of biovolume or for estimates of cell number by dividing filament length through average cell length. The most precise approach is to measure the length of the part of the filament within the counting grid or boundaries of the transect (Figure 13.2). Other methods for the quantification of filamentous algae and (cyano)bacteria have been proposed by Burnham et al. (1973) and Ramberg (1988).

Most counting approaches aim at counting only parts of the entire sample (i.e., the entire area or parts of the sediment chamber) and then extrapolate to the volume of the entire sample (Catherine et al., 2017). The most common methods are as follows:

- total area counting, that is, the counting of all cells in the sediment chamber. For most samples, this is very time-consuming and it is usually only applied to the counting of large units like colonies at low magnification; 
- counting of cells in transects from one edge of the chamber to the other, generally one vertical and one horizontal transect, passing through the centre of the chamber. Some inverted microscopes are equipped with special oculars so that the transect width can be adjusted as required. Alternatively, the horizontal or vertical sides of a simple counting grid can be used to indicate the margin of the transect. Extrapolation to the total sample requires measuring of the width of the transects and the diameter of the chamber or the counted total area, respectively, to calculate the area counted in proportion to the total area of the chamber bottom;

- counting of cells in randomly selected view fields. It is recommended that moving to consecutive view fields should be done without looking through the microscope to prevent a bias through subjective selection of fields. The view field area covered by a counting grid is usually considered as one field. However, if no counting grid is available, the total spherical view field can be considered as a single field. For an extrapolation to the total sample, the number of counted view fields, the area of a view field and the total area of the chamber are needed:

$$
N_{i}=c_{i} \times \frac{A_{\mathrm{C}}}{m \times A_{\mathrm{F}}}
$$

with $N_{i}$ : number of cells of species $i$ in the sample

$c_{i}$ : counts for species $i$

$A_{\mathrm{C}}$ : total area of the chamber bottom [in $\left.\mathrm{mm}^{2}\right]$

$A_{\mathrm{F}}$ : area of a view field [in $\mathrm{mm}^{2}$ ]

$m$ : number of counted view fields.

In a final step, the total number of cells is divided through the initial volume of the sample to yield cell densities in the sample.

$$
D_{i}=\frac{C_{i}}{V_{\mathrm{s}}}
$$

with $D_{i}$ : density of species $i$ in cells per litre

$V_{\mathrm{s}}$ : volume of sample [in L].

The density of different species in a sample can vary considerably for orders of magnitude, and there can also be difference in volume of individual species spanning orders of magnitude. It is therefore necessary to adopt the counting scheme for individual samples.

Total chamber area counting with low magnification $(100 \times)$ is suitable for large cells or multicellular units, whereas transect or field counting with higher magnification $(200 \times, 400 \times)$ is used for single cells or small units. Counting using transects or view fields assumes a homogeneous distribution of sedimented cells on the chamber's bottom. However, due to convection 
currents in the chamber, cells very rarely settle evenly on the bottom glass but often are found in higher densities in the centre and towards the borders of the chamber (Salmaso et al., 2017). Occasionally, density also varies between opposite borders of the chamber. Inhomogeneities can be minimised by stable ambient conditions during the sedimentation procedure, in particular by stable temperatures. Fortunately, transect counting of perpendicular diameters minimises the error and is hence the preferred method.

The accuracy of the counting increases with the ratio of counted to total area. But instead of counting the total area for each sample, a trade-off between time spent on counting and accuracy is to be made. The relation of accuracy to counting time is very effective when at least 100 units (cells, colonies, filaments) of a target taxon are counted (for simplification, see Box 13.1). In this case, the counting error is estimated at $20 \%$, while for reducing the error to 10\%, 400 units need to be counted (Lund et al., 1958). These percentages should be considered when deciding about the number of units of target species to be counted.

\section{BOX 13.I: SIMPLIFICATION FOR BIOMASS ESTIMATES}

With some experience and a flexible approach, the time needed for counting of cells and measuring cell dimensions can be considerably reduced without substantial loss of accuracy by applying the following procedures:

- If the difference in counts of dominant species in two perpendicular transects is less than $20 \%$, no further transects need to be counted.

- If the relative standard deviation (standard deviation divided by the mean) of cell dimensions measured on 10 cells is less than $20 \%$, no further cells need to be measured.

- If a set of samples from the same waterbody and only slightly differing sites (e.g., vertical or horizontal profiles, time series) is analysed, count all samples, but measure cell dimensions only in one. Visually estimate whether the size deviation of cells of the same species in other samples is not more than about $30 \%$ from the established average.

Objects often occur on the border of a view field, and it needs to be decided whether to count them or not. One simple solution is to ignore objects that touch left border while counting those that touch the right border or vice versa.

There are different recommendations regarding the number of units per species that must be counted to obtain sufficiently accurate data (Edler \& Elbrächter, 2010; Karlson et al., 2010). As stated above, counting 100 units per taxon generally gives acceptable data. Yet, in natural plankton communities, several tens of taxa are normally present, of which only a 
small number makes up a large share of total cells. For these dominant taxa, fairly accurate counting can be rapidly achieved, while for subdominant or rare taxa, this may not be achieved or is very time-consuming. Unless subdominant or rare taxa are considered important for hazard assessment, counting of 400-800 units in total has been found to yield globally acceptable results with a total overall error of some $10 \%$, an error of $10-20 \%$ for the dominant species and an error of $20-60 \%$ for subdominant species, respectively (Vuorio et al., 2007). For rare species (e.g., less than 10 counts out of 400), reliable cell density data can be derived only by increasing the number of counted view fields. In case of larger cells, the entire bottom area of the chamber may be counted at a lower magnification. If only cyanobacteria are to be counted, and only one or two taxa are present, counting with an error below $10 \%$ can be achieved within less than one hour by counting 400 individual units per taxon.

The use of mechanical or electronic counters for recording cell counts can shorten counting time considerably, especially if only a few taxa are counted. Computer keyboards can also be used together with suitable programmes for recording cell counts.

The use of an inverted microscope with counting chambers is generally the best approach for estimating cyanobacterial numbers. However, a standard microscope is sufficient for preconcentrated samples or for naturally dense samples from mass developments, provided the volume of the counted sample can be precisely defined, for example, by using a micropipette. Other counting chambers (e.g., Sedgewick-Rafter or haemocytometer) are available for use with a standard microscope. It can also be useful to monitor samples under high magnification with oil immersion $(1000 \times)$ to check the sample for the presence of very small cells, which may be overlooked during normal counting.

\subsection{I.3 Quantification of cyanobacteria using a standard microscope}

An alternative counting method which has been found to be useful is syringe filtration. This method is considerably less time-consuming because it does not depend on lengthy sedimentation times and uses a standard laboratory microscope. However, the results generally are less accurate because the recognition of cells on the membrane is hampered considerably by the opaqueness of the membrane filter.

\section{Equipment}

- Syringe, $10 \mathrm{~mL}$

- Membrane filters, $13 \mathrm{~mm}$ diameter with $0.45 \mathrm{~m}$ pore size

- Membrane filter holder adaptable to syringe (generally, a Luer connection)

- Glass microscope slides and cover glass

- Standard laboratory microscope with $100 \times$ and $400 \times$ magnification 


\section{Reagents}

- Immersion oil

\section{Procedure}

1. Gently mix sample by inverting several times.

2. Take up a defined volume of sample into the syringe. The volume is to be adjusted to the estimated cell density in the sample. Ten millilitres is a good starting point for most samples.

3. Connect filter holder with filter to the syringe.

4. Pass the sample through the filter, but avoid heavy pressure. When the filter is clogged, repeat from step 1 with a smaller volume.

5. Once the complete sample volume has passed through the filter, remove the filter from the holder and place it on a glass microscope slide with the surface with the captured cells facing upwards.

6. Allow the filter to dry at room temperature, then carefully add one or two drops of immersion oil to the filter. The oil will make the filter appear transparent and permit observation of the plankton cells trapped on its surface.

7. Finally, cover the filter surface with a cover glass and examine under the microscope.

8. The density of cyanobacteria can be easily calculated from counts of cells on the filter (or part of it), the total area of the filter and the volume of sample filtered.

\subsubsection{Estimation of cyanobacterial biomass by microscopy}

For estimation of toxin concentrations, cell numbers may be only of limited value as cell size varies considerably between and within species. Hence, an estimate of biomass is a better parameter to assess potential toxicity. Two principle approaches are available: estimating biomass from cell counts and average cell volumes, or chemical analysis of pigment content.

\subsection{I.4 Cyanobacterial counts and cell volumes}

Biovolume can be obtained from cell counts by determining the average cell volume for each taxon or unit counted and then multiplying this value by the cell counts in the sample. While by assuming a specific weight of ca. 1 $\mathrm{mg} / \mathrm{mm}^{3}$ (= $1 \mathrm{~g} / \mathrm{cm}^{3}$; wet weight) for planktonic cells, the biovolume can be transformed to (fresh) biomass, giving results as biovolume avoids errors of this assumption and has become widely accepted. Average cell volumes are determined by assuming idealised geometric shapes for individual taxa like regular spheres for Microcystis cells and elongated cylinders for filaments of Planktothrix. Measuring the relevant geometric dimensions of 10-30 cells (depending upon variability) of each taxon allows computing 
of the corresponding average volume (Hillebrand et al., 1999; CEN, 2015). This is best done with the aid of a spreadsheet in which the computing steps have already been defined based on general formulae (Table 13.2). Cyanobacteria have fairly simple geometric shapes (in contrast to some

Table 13.2 Biovolume calculation for common shapes of cyanobacterial cells

\begin{tabular}{|c|c|c|c|c|}
\hline Shape & Taxon & Formula & $\begin{array}{c}\text { Exemplary } \\
\text { dimensions } \\
\text { in } \mu \mathrm{m}\end{array}$ & $\begin{array}{l}\text { Biovolume } \\
\text { in } \mu m^{3}\end{array}$ \\
\hline \multirow[t]{6}{*}{ Sphere } & Aphanocapsa & $V=\pi / 6 \times d^{3}$ & $d=0.8$ & 0.27 \\
\hline & Chroococcus & & $d=2$ & 4.2 \\
\hline & Synechococcus & & $d=3$ & 14 \\
\hline & Microcystis & & $d=4$ & 34 \\
\hline & Microcystis & & $d=5$ & 65 \\
\hline & Microcystis & & $d=6$ & 113 \\
\hline \multirow{6}{*}{$\begin{array}{l}\text { Prolate } \\
\text { Spheroid } \\
\text { (rotational } \\
\text { ellipsoid) }\end{array}$} & $\begin{array}{l}\text { Aphanothece } \\
\text { (cell) }\end{array}$ & $V=\pi / 6 \times d^{2} \times h$ & $d=1.2, h=2.5$ & 1.9 \\
\hline & Radiocystis (cell) & & $d=3, h=4$ & 19 \\
\hline & $\begin{array}{l}\text { Dolichospermum } \\
\text { (cell) }\end{array}$ & & $d=4, h=6$ & 50 \\
\hline & $\begin{array}{l}\text { Dolichospermum } \\
\text { (cell) }\end{array}$ & & $d=5, h=7$ & 92 \\
\hline & $\begin{array}{l}\text { Dolichospermum } \\
\text { (filament) }\end{array}$ & $V=\pi / 6 \times d^{2} \times h \times n$ & $d=3, h=4, n=80$ & 942 \\
\hline & $\begin{array}{l}\text { Dolichospermum } \\
\text { (filament) }\end{array}$ & & $d=4, h=6, n=50$ & 3770 \\
\hline \multirow[t]{7}{*}{ Cylinder } & Limnothrix (cell) & $V=\pi / 4 \times d^{2} \times h$ & $d=2.5, h=10$ & 49 \\
\hline & $\begin{array}{l}\text { Planktothrix } \\
\text { (cell) }\end{array}$ & & $d=5, h=5$ & 98 \\
\hline & $\begin{array}{l}\text { Planktothrix } \\
\text { (cell) }\end{array}$ & & $d=8, h=5$ & 251 \\
\hline & Moorea (cell) & & $d=20, h=3$ & 942 \\
\hline & $\begin{array}{c}\text { Planktothrix } \\
\text { (filament) }\end{array}$ & $V=\pi / 4 \times d^{2} \times I$ & $d=5, I=300$ & 5890 \\
\hline & $\begin{array}{c}\text { Planktothrix } \\
\text { (filament) }\end{array}$ & & $d=8, I=450$ & 22619 \\
\hline & $\begin{array}{l}\text { Moorea } \\
\text { (filament) }\end{array}$ & & $d=20, I=I 500$ & $47 \mid 238$ \\
\hline
\end{tabular}

For more complex shapes, see Hillebrand et al. (1999) and Napiórkowska-Krzebietke \& Kobos (2016). The volumes presented here as examples should not be used for biovolume estimates in real samples. For samples to be analysed, the cell dimensions of encountered taxa have to be measured for biovolume calculations.

$V: \quad$ volume; $d$ : cell diameter; $h$ : cell height; l: filament length; $n$ : number of cells in filament. 
diatoms, Desmidiaceae or dinoflagellates, the shape of which needs to be approximate by combinations of simple shapes such as cylinders, cones and ellipsoids (Padisák \& Adrian, 1999; Napiórkowska-Krzebietke \& Kobos, 2016)). Table 13.2 gives exemplary shapes, dimensions and biovolumes of cyanobacteria. From the numbers in the table, it is evident that cell dimensions need to be determined as accurately as possible to minimise the error of biovolume estimates. Linear dimensions such as cell diameter and cell volume are related by a cubic function, and therefore, a measurement error of cell diameter of $25 \%$ (e.g., 5 versus $4 \mu \mathrm{m}$ cell diameter) results in an error of $95 \%$ in biovolume. In consequence, while using mean cell volumes from literature, compiled from other waterbodies (e.g., as given in Kremer et al., 2014), provides more meaningful data than mere cell counts, the accurate measurement of cells in samples from the waterbody under study is more accurate.

Example 1: By measuring 20 Microcystis cells, an average diameter of $5 \mu \mathrm{m}$ was established. Assuming spherical-shaped cells, the average cell volume is $\pi / 6 \times 5^{3} \mu \mathrm{m}^{3}=65.4 \mu \mathrm{m}^{3}$. Counting resulted in 100000 cells per $\mathrm{mL}$, and thus, the total biovolume is $65 \times 10^{5} \mu \mathrm{m}^{3} / \mathrm{mL}=6.5 \times 10^{9}$ $\mu \mathrm{m}^{3} / \mathrm{L}=6.5 \mathrm{~mm}^{3} / \mathrm{L}$.

Example 2: Measuring 30 Planktothrix filaments resulted in an average length of $L=225 \mu \mathrm{m}$ and an average diameter of $6 \mu \mathrm{m}$. Assuming cylindrical filaments, the average filament volume is $\pi / 4 \times 6^{2} \times 225$ $\mu \mathrm{m}^{3}=6362 \mu \mathrm{m}^{3}$. Enumeration resulted in 1000 filaments per $\mathrm{mL}$. Thus, the biovolume of Planktothrix was $6362 \times 10^{3} \mu \mathrm{m}^{3} / \mathrm{mL}=6.4 \times 10^{9}$ $\mu \mathrm{m}^{3} / \mathrm{L}=6.4 \mathrm{~mm}^{3} / \mathrm{L}$.

Thus, although the number of Planktothrix filaments was 100 -fold less than that of Microcystis cells, biovolumes were similar. Both species often contain microcystins, and it is possible to compare the relative toxin content per biovolume or biomass, whereas there is little point in comparing toxin content in relation to the cell or filament counts, respectively.

\section{I3.4 ESTIMATION OF PHYTOPLANKTON BIOMASS USING CHLOROPHYLL-a ANALYSIS}

The pigment chlorophyll-a generally contributes $0.5-1 \%$ of fresh weight of phytoplankton organisms (Kasprzak et al., 2008). Although the pigment content may vary depending on the physiological state of the organisms (see section 4.6.5), chlorophyll- $a$ is a widely used and accepted measure of total phytoplankton biomass. It is an especially useful measure during cyanobacterial blooms, when the phytoplankton mainly consists of cyanobacteria, often of only one or a few taxa. 
In modern laboratories, the analysis of chlorophyll and other pigments (carotenoids) is often done by HPLC (Bidigare et al., 2005). A number of methods have been described, and it is beyond the scope of this book to review these. In general, HPLC is the most accurate method for pigment analysis but much more expensive than the photometric approach described below. For most surveillance and monitoring practices, the latter is accurate and specific enough. Nevertheless, occasional parallel analysis of a single sample by HPLC and photometry is valuable to estimate the accuracy of the data.

Photometric analysis of chlorophyll- $a$ requires relatively simple laboratory equipment, principally a filtration device, a centrifuge and a spectrophotometer. It is considerably less time-consuming than microscopic biomass determination but less specific. Standard protocols are available (e.g., ISO, 1992), but methods vary somewhat between laboratories. The main steps in most methods are essentially the same: solvent extraction of chlorophyll- $a$, determination of the concentration of the pigment by spectrophotometry and correction for pheophytin $a$, a degradation product of chlorophyll- $a$. The need for the latter, however, has been disputed (Stich \& Brinker, 2005). Especially when chlorophyll- $a$ concentrations are low, the correction for pheophytin $a$ may introduce a bias and underestimate chlorophyll- $a$ concentrations (or even lead to calculated negative concentrations). In case a correction for pheophytin $a$ is not performed, the reported values should be declared as "chlorophyll- $a$ not corrected for pheophytin $a$ " or as "chlorophyll- $a$ including pheophytin $a$ ".

A simple method following the ISO procedure involving an extraction step with $90 \%$ aqueous ethanol (Sartory \& Grobbelaar, 1984), for the determination of chlorophyll- $a$ in a field sample, is outlined here. Notably, extraction in $90 \%$ acetone instead of $90 \%$ ethanol according to Strickland \& Parsons (1972) is applied in some studies.

\section{Equipment}

- Spectrophotometer suitable for readings up to $750 \mathrm{~nm}$, or photometer with discrete wavelengths at 665 and $750 \mathrm{~nm}$

- Glass cuvettes, typically of $1 \mathrm{~cm}$ path length, or $5 \mathrm{~cm}$ for expected very low concentrations

- Centrifuge

- $15-\mathrm{mL}$ centrifuge tubes, graduated and with screw caps

- Water bath at $75^{\circ} \mathrm{C}$ or other heating device for heating ethanol

- Glass fibre filters, ca. $50 \mathrm{~mm}$ diameter, fitting to the filtration apparatus

- Filtration apparatus and vacuum pump

- Tissue homogeniser or ultrasonication device

- Pipette or similar for the addition of acid

\section{Reagents}

- $90 \%$ aqueous ethanol

- $1 \mathrm{M}$ hydrochloric acid 


\section{Procedure}

Perform the following steps in low intensity of indirect light because light induces a rapid degradation of chlorophyll.

1. Filter a defined volume of water through a glass fibre filter as soon as possible and store the filter with the loaded face folded on itself in individual, labelled bags or tubes. If extraction cannot be performed immediately, filters should be stored $-20^{\circ} \mathrm{C}$ or better at $-80^{\circ} \mathrm{C}$. For extended storage, freeze-drying of samples is strongly recommended to avoid degradation. Alternatively to freezing, samples can be stored in the extraction solvent (see below) for up to 4 days in the refrigerator.

2. Place the filter in a tissue homogeniser, add $2-3 \mathrm{~mL}$ of boiling ethanol (working with effective ventilation, preferably using a fume cupboard) and homogenise until the filter has been completely disintegrated. Samples can also be homogenised by ultrasonication or manual grinding using mortar and pestle. Pour the sample sludge into a centrifuge tube, rinse out the grinding tube with another $2 \mathrm{~mL}$ ethanol and add this to the centrifuge tube. Repeat this step. Make up to a total of $10 \mathrm{~mL}$ in the centrifuge tube with $90 \%$ ethanol. Seal the tube, label and store in darkness at approximately $20^{\circ} \mathrm{C}$ for $24-48 \mathrm{~h}$.

3. Centrifuge for $15 \mathrm{~min}$ at $3000-5000 \mathrm{~g}$ to clarify samples. Decant the clear supernatant into a clean vessel and record the volume.

4. Blank spectrophotometer with $90 \%$ ethanol over the wavelength range of $650-800 \mathrm{~nm}$.

5. Transfer a volume of clear sample to the cuvette and record absorbance at $750 \mathrm{~nm}$ and $665 \mathrm{~nm}$ [readings $\mathrm{A}(750 \mathrm{a})$ and $\mathrm{A}(665 \mathrm{a})$ ]. Absorbance (A) at $665 \mathrm{~nm}$ should range between 0.1 and 0.8 . If higher, the sample should be diluted with $90 \%$ ethanol; if lower, a cuvette with a longer optical path should be used.

6. If correction for pheophytin was desired, add $30 \mu \mathrm{L}$ of $1 \mathrm{M} \mathrm{HCl}$ per $\mathrm{mL}$ of sample volume in cuvette and agitate gently for $1 \mathrm{~min}$. Record absorbance at $750 \mathrm{~nm}$ and $665 \mathrm{~nm}$ [readings $\mathrm{A}(750 \mathrm{~b})$ and $\mathrm{A}(665 \mathrm{~b})]$.

\section{Calculation}

1. Correct for turbidity: $\mathrm{A}(665 \mathrm{a})-\mathrm{A}(750 \mathrm{a})=\mathrm{A}(665 \mathrm{a}$, corrected $)$ and $\mathrm{A}(665 \mathrm{~b})-\mathrm{A}(750 \mathrm{~b})=\mathrm{A}(665 \mathrm{~b}$, corrected $)$

2. The concentrations of chlorophyll- $a$ and pheophytin $a$ are calculated:

$$
\begin{aligned}
& \text { chlorophyll } a=\frac{29.62\left(\mathrm{~A}_{(665 \mathrm{a}, \text { corrected })}-\mathrm{A}_{(665 \mathrm{~b}, \text { corrected })}\right) \times V_{\mathrm{e}}}{V_{\mathrm{s}} \times l} \mu \mathrm{g} / \mathrm{L} \\
& \text { pheophytin } a=\frac{20.73\left(\mathrm{~A}_{(665 \mathrm{~b}, \text { corrected })}\right) \times V_{\mathrm{e}}}{V_{\mathrm{s}} \times 1} \mu \mathrm{g} / \mathrm{L}
\end{aligned}
$$


with: $V_{\mathrm{e}}=$ volume of ethanol extract in $\mathrm{mL}$

$V_{\mathrm{s}}=$ volume of water sample in $\mathrm{L}$

$l=$ path length of cuvette in $\mathrm{cm}$.

Simplifications of the procedure may be applied. If no centrifuge for volumes of $10 \mathrm{~mL}$ is available, filtration may be used instead. In case neither tissue homogeniser nor ultrasonication device nor mortar and pestle are available, proceed without the homogenisation step. Underestimations of chlorophyll- $a$ concentrations may occur, but for cyanobacteria, these are not likely to be substantial. Other solvents - N, N-dimethylformamide, dimethyl sulfoxide and acetone - have also been used for extraction (Speziale et al., 1984), but ethanol has the advantage of being less toxic and compatible with polymeric materials (Ritchie, 2006).

\section{I3.5 PHYTOPLANKTON AND CYANOBACTERIA QUANTIFICATION BY FLUORESCENCE ANALYSIS}

As cyanobacterial biomass and community composition is highly inconstant in space and time, a quantification approach that is able to follow this variability is valuable. Standard method for phytoplankton quantification is based on the microscopic analyses of samples processed in the laboratory, complemented by chlorophyll- $a$ analysis by spectrophotometer or spectrofluorimeter. Such results are based on the discrete sampling of individual localities at certain time and horizons. Equipment used in this type of monitoring is relatively cheap and has an acceptable sensitivity, but the analytical results are available only with a delay of hours or days and, depending on the frequency of sampling, by discrete sampling potential threats due to high cyanobacterial abundance can be missed such as short-lived surface blooms of cyanobacteria or the fast and rapid shifts of water quality due to quick hydrological or meteorological changes.

Advanced methods for phytoplankton quantification could be able to describe the variability, permanent changes and displacement of phytoplankton biomass and the spatial (vertical and horizontal) and temporal variability in a waterbody with the sensitivity and information frequency sufficient for the water management (raw water takeoff), or ecological understanding (developments and dynamic of phytoplankton assemblages).

Advanced methods for phytoplankton quantification include the following:

- remote sensing and satellite imagery based on radiometry (AVHRR Advanced Very High-Resolution Radiometer, hyperspectral landscape imaging, etc. (Kahru \& Brown, 1997));

- airborne- and satellite-based optical remote sensing including hyperspectral phytoplankton imaging, etc. (see section 11.10); 
- optical in situ methods (in situ flow cytometry, analytical flow cytometry etc);

- In situ and online fluorescence quantification of dominant phytoplankton pigments including - automatic high-frequency monitoring (AHFM) systems.

While radiometry (AVHRR) was used for the water quality monitoring already 20 years ago (Kahru \& Brown, 1997), the MODIS (Moderate Resolution Imaging Spectroradiometer) uses more and more detailed coefficients for correction of variabilities in the satellite phytoplankton quantification at the present time (Sayers et al., 2016). Airborne (airplane, drone etc.) remote sensing is based mostly on optical methods like hyperspectral imaging. This technology has recently been adopted for the advanced quantification of phytoplankton, including the correction for reflectance or humidity (Wang et al., 2016; Wolanin et al., 2016).

Besides monitoring of phytoplankton, remote sensing can be used to assess other properties of water ecosystems (see also section 11.10). For example, laser scanning can be used for bathymetry of shallow waters (Fernandez-Diaz et al., 2014) or for mapping sediments disposal (Montreuil et al., 2014). Hyperspectral data can be used for depth estimation in shallow waters (Ma et al., 2014), suspended inorganic particles (Giardino et al., 2015) or dissolved organic matter (Zhu et al., 2013). All these parameters are highly relevant for water quality monitoring; however, the objective of this chapter is to demonstrate possibilities of fluorescence and imaging spectroscopy to assess phytoplankton and cyanobacterial blooms by measuring concentrations of photosynthetical pigments.

The majority of real-time technologies employed for cyanobacterial management are based on fluorescence of pigments (Zamyadi et al., 2016). Each of the fluorescent pigments present in cyanobacterial or generally in algal cells, respectively, has a specific excitation and emission spectrum (see Table 13.3). chlorophyll- $a$ is a photosynthetic pigment present in all species of phytoplankton, including eukaryotic (algae) and prokaryotic organisms (cyanobacteria), and thus, it is a good and commonly used indirect marker of the total phytoplankton biomass. Standard methods of its

Table 13.3 Excitation and emission maxima of dominant pigments and their general distribution among particular phytoplankton groups

\begin{tabular}{llcl}
\hline Pigment & \multicolumn{1}{c}{ Group } & Excitation $(\mathrm{nm})$ & Emission $(\mathrm{nm})$ \\
\hline chlorophyll-a & Green algae, & 440 & 685 \\
Chlorophyll-c & Cryptophyceae & 460 & 685 \\
Carotenoids & Diatoms, Chrysophyceae & $500-550$ & 685 \\
Phycoerythrin & Cryptophyceae, Cyanobacteria & $560-585$ & $590,620,685$ \\
Phycocyanin & Cyanobacteria & $610-620$ & 645,685 \\
\hline
\end{tabular}


quantification are based on the extraction of the pigment into an organic solvent and subsequent determination by spectrophotometry (Richards \& Thompson, 1952), fluorimetry (Holm-Hansen et al., 1965) or chromatography (Jacobsen, 1978; Otsuki \& Takamura, 1987). These methods have been routinely used for decades, but they are time-consuming and require a standard sampling, transport to the laboratory and immediate processing, as well as an experienced analyst. Furthermore, all steps of the process from water sampling to the final photometric determination of the chlorophyll- $a$ content can be a source of variability. Other disadvantage is a comparatively large volume of sample needed and thus a limitation with respect to the number of samples taken and the possible changes during the sample transport and storage, namely, degradation.

One of the key characteristics of chlorophyll- $a$ is its fluorescence. Photosystem II (PS II), which is mainly responsible for the chlorophyll fluorescence, consists of peripheral and core antenna. The first contains a species-dependent pigment absorbing quantum of light, the latter an evolutionary conserved molecule of chlorophyll- $a$ (Beutler et al., 2002). Most of the energy transferred from the peripheral antenna to the core is used for photochemistry and thermal decay and several percent for fluorescence by emitting light at wavelength around $685 \mathrm{~nm}$ (red light). Measurement of this light serves as a tool for the in vivo determination of chlorophyll-a. Fluorescence of chlorophyll- $a$ also enables its determination in the field studies, directly in the water column. Connecting the fluorimeter in continuous or stop flow mode to the pumping system, which brings water to the measuring cell of the fluorimeter, is one of the possibilities of the online monitoring of chlorophyll- $a$ (Pinto et al., 2001; Odate et al., 2002; Goddard et al., 2005). The phytoplankton can be measured directly in the water column, and there is evidence from several studies that data are similar to those gained by standard microscopic analyses or chlorophyll- $a$ quantification after solvent extraction and spectrophotometric analysis (Gregor \& Maršálek, 2004; Gregor et al., 2005; Izydorczyk et al., 2005; Gregor et al., 2007). Estimation of cyanobacterial biomass or cell density is possible by measuring phycocyanin (PC) fluorescence (Figure 13.3).

Asai et al. (2001) presented a sensor with two fluorescence channels - the first one for detecting chlorophyll- $a$ of eukaryotic algae (excitation $440 \mathrm{~nm}$, emission $680 \mathrm{~nm}$ ) and the second one for detecting the cyanobacteria-specific PC (excitation $620 \mathrm{~nm}$, emission $645 \mathrm{~nm}$ ). An in situ fluorimeter with three excitation bands and detection of emission from 546 to $733 \mathrm{~nm}$ was also designed (Desiderio et al., 1997). In situ fluorimeters include devices measuring each sample individually, with continuous circulation of water samples (flow-through) or with submersible probes. Submersible probes for detecting only chlorophyll- $a$, a combination of sensors for the detection of chlorophyll and phycocyanin (PC), or more phytoplankton classes are commercially available from manufacturers around the globe. They contain 
(a)

(b)

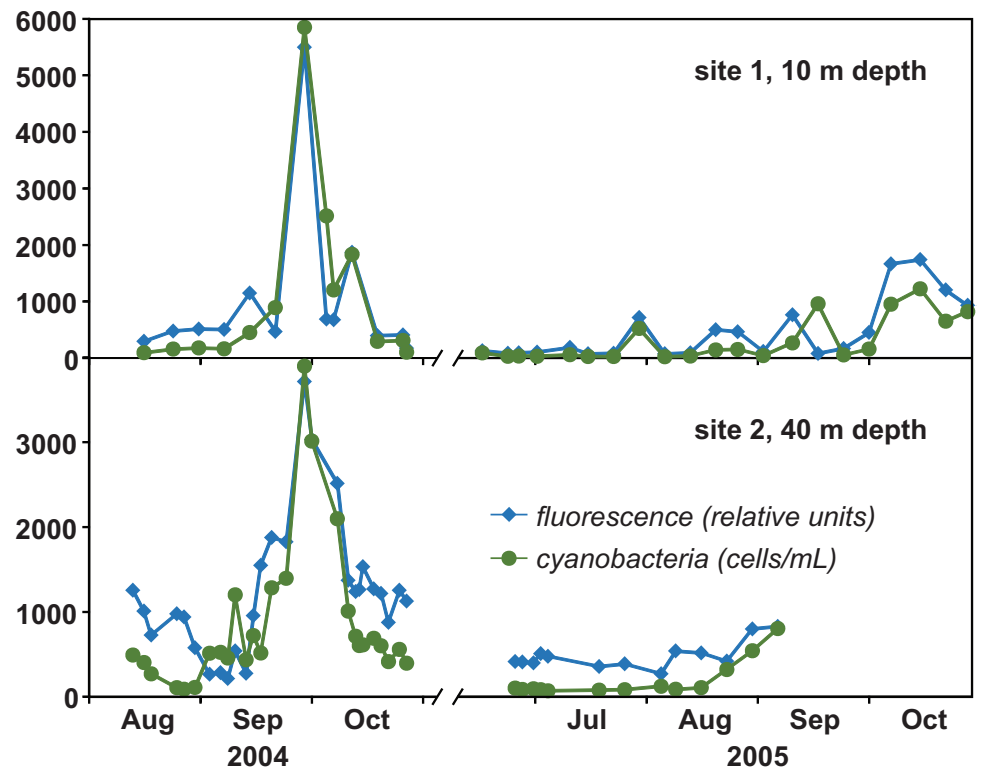

Figure 13.3 Seasonal dynamics of phycocyanin fluorescence (F590) and cyanobacteria cell counts at two individual sampling points in a drinking-water reservoir at $10 \mathrm{~m}$ depth (a) and $40 \mathrm{~m}$ depth (b).

diodes emitting light of defined wavelength bands for excitation of pigments and the response is measured as the fluorescence. These instruments are usually connected to a computer for operation and data storage. This design allows submersion of the probe to a defined depth, limited only by the cable length.

Submersible in situ fluorimeters are suited for online and real-time monitoring of spatiotemporal dynamics of cyanobacterial populations, for example, at raw water offtake sites for drinking-water production. They have acceptable sensitivity and are suitable for differentiation between algae and cyanobacteria (Zamyadi et al., 2016). When used for real-time management purposes, it is crucial that devices are well maintained, especially the regular cleaning of optical sensors is critical or the control of automatic cleaning system, respectively. Further, fluorescence measurements in a particular waterbody are preferably calibrated against other parameters of phytoplankton or cyanobacterial biomass, for example, cell counts (Figure 13.4).

Submersible fluorimeters are not suitable for species identification or assessment of the physiological status. The most important sources of variability of in situ measurements are interferences with weather (wind, sunshine), water turbidity, temperature, cyanobacterial morphology (colony, filaments, picocyanobacteria) and sensor types (Hodges et al., 2018). It is known that data 


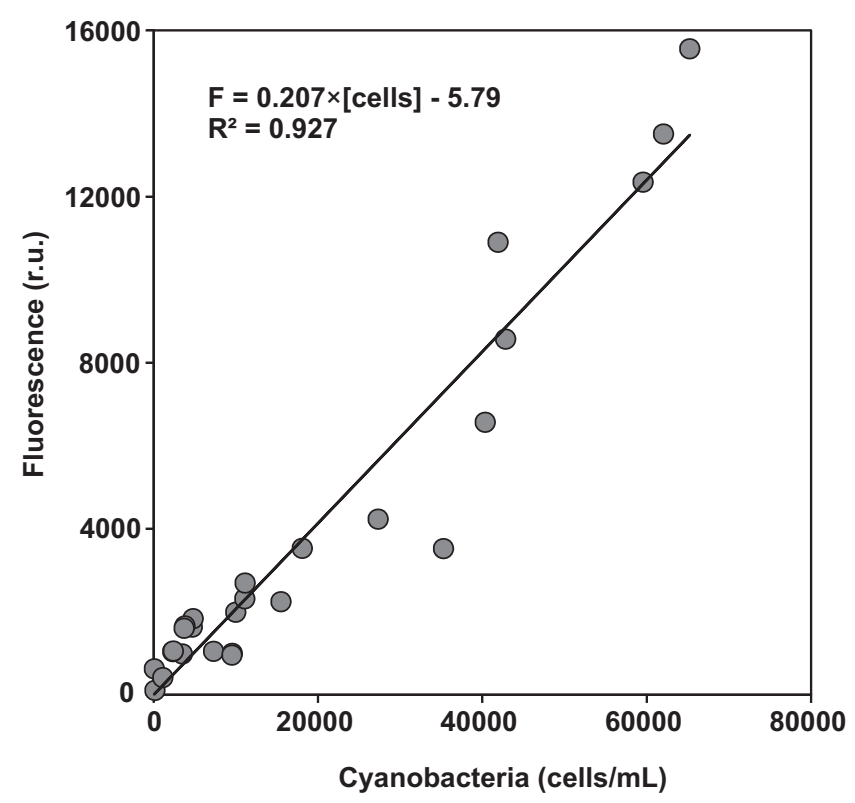

Figure 13.4 Comparison of quantitative assessment of cyanobacterial cell density by microscopic cell counts and chlorophyll fluorescence in samples from Brno reservoir $(n=43)$. r.u.: relative units of fluorescence.

produced by these devices in dense cyanobacterial blooms may underestimate the real situation and should be corrected (Silva et al., 2016). Another parameter which was studied is optical interaction of algae and cyanobacteria in phytoplankton. The optimal correction method can be selected for each fluorimeter and cyanobacteria species pairs by validating against data from the investigation of green algae as an interference source (Choo et al., 2019).

Some general discrepancies can be found when comparing submersible fluoroprobes, spectrophotometric chlorophyll- $a$ quantification and cell counts, even when the same or similar species are analysed. The probable explanation is a varying level of pigments among species and within species at different phases of growth. Other potential sources of variability include different sampling strategies (continuous and online measurement versus discrete sampling), sample treatment and mode of transport to the laboratory. Another source of the differences between results was observed where picocyanobacteria are present and less experienced and skilled laboratory staff overlooks their presence, but fluorescence probes takes them into account.

Submersible devices usually measure in a continuous mode; that is, they enable data to be obtained from the whole water column in a much shorter time compared to discrete sampling. This is especially useful when phytoplankton organisms occur in a narrow horizontal layer like Planktothrix 
rubescens in the metalimnion (see Chapters 4,8 and 11) or to monitor the development of surface blooms at critical sites. In these cases, conventional methods based on discrete samples with the inherent lag time may miss ephemeral risks from cyanotoxins.

\subsection{Recent advances and future direction in the phytoplankton and cyanobacteria quantification by fluorescence analysis}

Cyanobacterial blooms that show a high and dynamic variability in time, space and abundance can be efficiently monitored by advanced fluorescence probe technology, which has become far more advanced in recent years with specific light-emitting diodes (LEDs) and optical filters. However, recent widespread application of in situ fluorimetric probes by both scientists and water managers has led to recognition of interferences, sources of variability and difficulties in comparison with the results. One common problem of in situ and online monitoring by fluorescence and optical sensors is biofouling. That is why the regular and preferably automatic cleaning of probes is extremely important.

Automatic high frequency monitoring (AHFM) systems are an important recent development which has increased not only the measurement frequency, but also the number of variables being monitored in waterbodies. Broad spectrum of sensors can be used on demand according to the monitoring purposes, like the ion-selective electrodes, UV absorbance, fluorescence and biochip probes (Marce et al., 2016). While full automation is already possible for probes based on optical properties (absorbance and fluorescence), this is still difficult for ion-selective electrodes and biochips. Main challenges are low limits of detection required for micropollutants and sensor maintenance requirements.

We can expect the combination of approaches for phytoplankton quantification in the near future. An approach useful in practice is to use submersible fluorescence probes for quantification of phytoplankton biomass based on AHFM systems in combination with hyperspectral or selective spectral cameras operated from airplanes or drones, which can describe the spatial variability of cyanobacterial biomass in waterbodies. As the data from AHFM systems are used by a number of institutions, calibration, validation and corrective coefficients for data comparison are particularly important (Bertani et al. 2017).

Further, new simple models of fluorometers for the quantification of algae and cyanobacteria using widely available devices like smart phones have been proposed (Friedrichs et al., 2017). Once calibration and variability in fluorescence signals are mastered, respective adapters can become effective tools.

New compact multiwavelength fluorimeters with modular design are highly versatile and flexible monitoring tools. Detection modules for green 
algae, cyanobacteria and dinophytes allow the continuous identification and quantification of the major relevant algal groups based on their spectral characteristics with a detection limit of 10 cells/L (Zieger et al., 2018). The sensitivity of most types of submersible fluorescence probes is equivalent to $1000-2000$ cells $/ \mathrm{mL}$, which is acceptable for general monitoring. For sensors installed for in situ monitoring, biofouling is one of the most important sources of variability requiring a regular and thorough maintenance and verification. A disadvantage of several devices is that no correction on the turbidity is performed, which may be important in natural conditions.

There is new information highlighting the potential for multiparameter monitoring via fluorescence spectroscopy; fluorescence spectra can predict both microcystin-LR occurrence and disinfection by-products formation potential in the waterbody (Brophy et al., 2018).

An overview of new devices for in situ fluorescence phytoplankton quantification and discrimination, including the limitation and interference factors, is given by Bertone et al. (2018).

\section{I3.6 MONITORING TOXIGENIC CYANOBACTERIA BY MOLECULAR METHODS}

Molecular methods have significantly increased our understanding on the distribution of genes involved in the production of toxins within the phylum cyanobacteria (see Sivonen \& Börner, 2008 and Dittmann et al., 2013). This subchapter introduces the molecular detection of toxigenic cyanobacteria not only in surface waters such as lakes, rivers and drinking-water reservoirs but also in food supplements. Genetic methods are only able to indicate the potential of toxin synthesis and do not provide information about actual toxin production and concentrations. Nevertheless, applications in monitoring include early warning of the toxin-producing potential of a developing bloom and allow the identification of the toxin-producing taxa in mixed field populations of cyanobacteria. They also allow tracing the development of the genotype composition of a taxon, that is, whether the fraction of toxin-producing genotypes changes over time. Moreover, these methods allow high-throughput sample analysis.

This section provides an overview of the workflow for applying genetic methods. For more detailed information, the reader is referred to a handbook providing more details on the scientific basis for the use of molecular tools, protocols and the interpretation of respective results (Kurmayer et al., 2017). Section 13.6.8 reviews applications in practice.

A full sequence of a biosynthesis gene cluster of a cyanobacterial toxin was first reported for microcystin from Microcystis sp. (Tillett et al., 2000). Sequences from other taxa and encoding the synthesis of other toxins rapidly followed, and today, sequences of biosynthesis genes for all major types of cyanobacterial toxins are available (see Table 13.4; Figure 13.5) 
Table 13.4 Overview on complete biosynthesis gene clusters reported for toxin types and various taxa of cyanobacteria

\begin{tabular}{|c|c|c|c|c|}
\hline Toxin & Organisms & Strain & Genes & Reference \\
\hline \multirow[t]{5}{*}{ Microcystin } & $\begin{array}{l}\text { Microcystis } \\
\text { aeruginosa }\end{array}$ & PCC 7806 & mcyA-J & $\begin{array}{l}\text { Tillett et al. } \\
(2000)\end{array}$ \\
\hline & $\begin{array}{l}\text { Planktothrix agardhii } \\
\text { Planktothrix } \\
\text { rubescens }\end{array}$ & $\begin{array}{l}\text { NIVA-CYA } \\
\text { I26-8 } \\
\text { NIVA-CYA } \\
98\end{array}$ & $m с y A-J, T$ & $\begin{array}{l}\text { Christiansen } \\
\text { et al. (2003) } \\
\text { Rounge et al. } \\
(2009)\end{array}$ \\
\hline & $\begin{array}{l}\text { Dolichospermum } \\
\text { (Anabaena) sp. }\end{array}$ & 90 & $m c y A-J$ & $\begin{array}{l}\text { Rouhiainen } \\
\text { et al. (2004) }\end{array}$ \\
\hline & Nostoc sp. & 152 & & $\begin{array}{l}\text { Fewer et al. } \\
(20 \mid 3)\end{array}$ \\
\hline & Fischerella sp. & PCC 9339 & & Shih et al. (2013) \\
\hline Nodularin & Nodularia spumigena & NSORIO & ndaA-G & $\begin{array}{l}\text { Moffitt \& Neilan } \\
(2004)\end{array}$ \\
\hline \multirow[t]{4}{*}{ Cylindrospermopsin } & $\begin{array}{l}\text { Raphidiopsis } \\
\text { (Cylindrospermopsis) } \\
\text { raciborskii }\end{array}$ & AWT205 & cyrA-O & $\begin{array}{l}\text { Mihali et al. } \\
(2008)\end{array}$ \\
\hline & Oscillatoria sp. & PCC 6506 & & $\begin{array}{l}\text { Mazmouz } \\
\text { et al. }(20 \mid 0)\end{array}$ \\
\hline & Aphanizomenon sp. & I0E6 & & $\begin{array}{l}\text { Stüken \& } \\
\text { Jakobsen (20।0) }\end{array}$ \\
\hline & Raphidiopsis curvata & $\begin{array}{l}\text { CHABII50, } \\
\mathrm{HBI}\end{array}$ & & Jiang et al. (20|4) \\
\hline \multirow[t]{5}{*}{ Saxitoxin } & $\begin{array}{l}\text { Raphidiopsis } \\
\text { (Cylindrospermopsis) } \\
\text { raciborskii }\end{array}$ & T3 & $s x t A-X$ & $\begin{array}{l}\text { Kellmann } \\
\text { et al. (2008) }\end{array}$ \\
\hline & $\begin{array}{l}\text { Microseira (Lyngbya) } \\
\text { wollei }\end{array}$ & $\begin{array}{l}\text { Carmichael / } \\
\text { Alabama }\end{array}$ & & $\begin{array}{l}\text { Murray } \\
\text { et al. }(201 \mathrm{I})\end{array}$ \\
\hline & $\begin{array}{l}\text { Dolichospermum } \\
\text { (Anabaena) circinale }\end{array}$ & AWQCI3IC & & $\begin{array}{l}\text { Murray } \\
\text { et al. }(201 \mathrm{I})\end{array}$ \\
\hline & Aphanizomenon sp. & $\mathrm{NH}-5$ & & $\begin{array}{l}\text { Murray } \\
\text { et al. }(201 \mathrm{I})\end{array}$ \\
\hline & Raphidiopsis brookii & D9 & & $\begin{array}{l}\text { Stucken } \\
\text { et al. }(20 \mid 0)\end{array}$ \\
\hline \multirow[t]{4}{*}{ Anatoxin-a } & Oscillatoria sp. & PCC 6506 & anaA-H & $\begin{array}{l}\text { Rantala-Ylinen } \\
\text { et al. }(201 \mathrm{I})\end{array}$ \\
\hline & $\begin{array}{l}\text { Dolichospermum } \\
\text { (Anabaena) sp. }\end{array}$ & 37 & & $\begin{array}{l}\text { Rantala-Ylinen } \\
\text { et al. }(20 \mathrm{I} \mathrm{I})\end{array}$ \\
\hline & Cylindrospermum sp. & PCC 74I7 & & $\begin{array}{l}\text { Calteau et al. } \\
(20 \mid 4)\end{array}$ \\
\hline & $\begin{array}{l}\text { Cuspidothrix } \\
\text { issatschenkoi }\end{array}$ & $\begin{array}{l}\text { CHAB D3, } \\
\text { RM-6, } \\
\text { LBRI48 }\end{array}$ & & $\begin{array}{l}\text { Jiang } \\
\text { et al. (20I5) }\end{array}$ \\
\hline Lyngbyatoxin & $\begin{array}{l}\text { Moorea producens } \\
\text { (Lyngbya majuscula) }\end{array}$ & & $I t x A-D$ & $\begin{array}{l}\text { Edwards \& } \\
\text { Gerwick (2004) }\end{array}$ \\
\hline
\end{tabular}

The species name and strain identifier are given as reported in the original publication. 


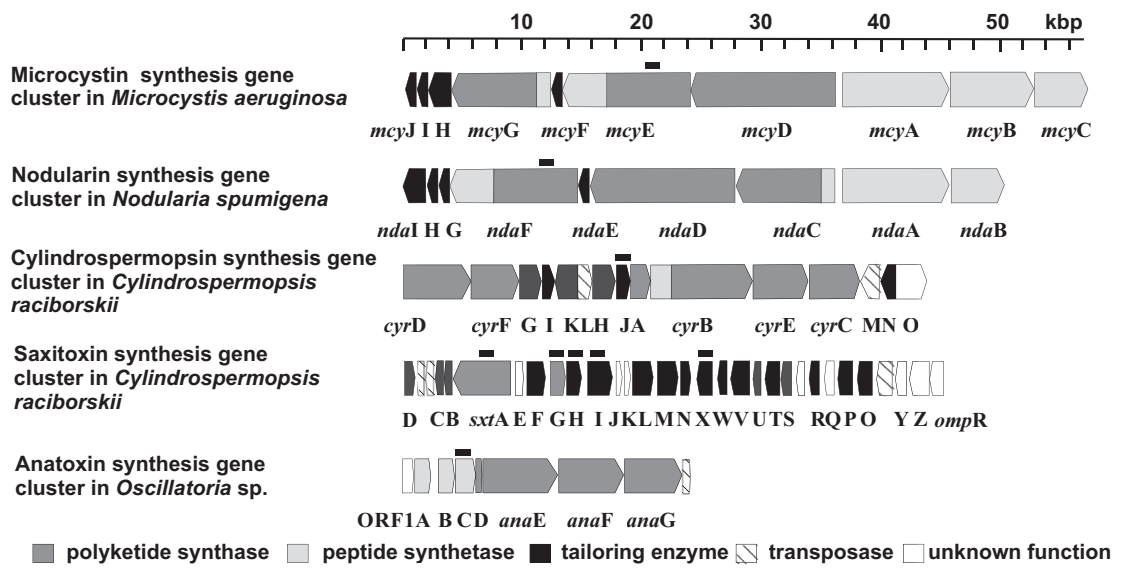

Figure 13.5 Overview of cyanotoxin synthesis gene clusters and PCR approach used for the detection of toxigenic genotypes. The PCR-amplified fragments and corresponding genes used to indicate potential toxin synthesis are indicated: mcyE/ndaF according to Rantala et al. (2004) and Jungblut and Neilan (2006); cyrJ (Mihali et al., 2008), sxtA, G, H, I, X (Casero et al., 2014), anaC (RantalaYlinen et al., 20II).

with the exception of anatoxin-a (S), the biosynthesis of which was still unknown by the time of publication of this book.

The elucidation of biosynthesis genes significantly increased the understanding on inheritance and evolution of cyanotoxin synthesis; that is, phylogenetic analyses lead to the conclusion that microcystin synthesis is an evolutionarily old feature that has been lost repeatedly during the evolution of cyanobacteria (Rantala et al., 2004). The genes involved in the synthesis of nodularin were probably derived from the genes encoding microcystin synthesis via a gene deletion event (Moffitt \& Neilan, 2004; Rantala et al., 2004). Similar to microcystin synthesis, for saxitoxin synthesis genes, the comparison of gene synteny and phylogeny between taxa as well as the evidence of strong stabilising selection suggested that saxitoxin synthesis genes have been mostly inherited vertically (as opposed to horizontal gene transfer) and emerged at least 2 billion years ago (Murray et al., 2011). The saxitoxin-producing dinoflagellates are eukaryotic toxic algae containing a third membrane of endoplasmatic reticulum around the chloroplast organelles and evolved from cyanobacteria through secondary or tertiary endosymbiosis during the late Paleozoicum (Lee, 2018). Generally, it is understood that in dinoflagellates, genes forming the core genes for saxitoxin synthesis (i.e., sxtA and $s x t G$ ) have been acquired via horizontal gene transfer from bacteria and have been lost repeatedly in various lineages (Orr et al., 2013; Murray et al., 2015). For the cylindrospermopsin-producing taxa, phylogenetic congruence between taxonomic marker genes and cylindrospermopsin synthesis genes was reported, implying the dominant 
influence of vertical inheritance in the course of the evolution of the phylum of cyanobacteria (Jiang et al., 2014). Finally, for anatoxin-a synthesis, the comparison of anatoxin synthesis genes revealed that gene nucleotide variability was congruent with phylogenetic analysis across cyanobacterial taxa (Jiang et al., 2015; Brown et al., 2016). In summary, phylogenetic analyses rather support the role of vertical inheritance or the loss of cyanotoxin synthesis genes than the role of frequent lateral gene transfer events.

Although genetic methods are only able to indicate the potential of toxin synthesis, they are showing promising results supporting risk assessment. If genes for toxin production were absent in a cyanobacterial population, this population would not be able to produce a specific toxin. Vice versa, this dependence is not as certain, and cyanobacteria carrying the genes may or may not produce a particular toxin; only toxin analyses can show that they are indeed producing this toxin and to which extent. Thus, based on the presence of genes, the molecular tools indicate the occurrence of toxigenic genotypes in the environment or in food supplements, but the actual toxin content or concentration must be determined using chemical-analytical techniques (see section 14.1). Currently, all the molecular tools available are based on the principle of polymerase chain reaction (PCR). Due to the generally high sensitivity of PCR, it is possible to detect toxigenic genotypes in minute amounts, that is, long time before a toxic cyanobacterial bloom may occur or as minor component in food supplements. Consequently, waterbodies bearing a risk of toxic bloom formation could already be identified early on in the growing season possibly assisting in an economically more efficient application of cyanotoxin detection techniques (see Box 13.2). Furthermore, early identification of toxigenic genotype occurrence may lead to a more detailed recording of environmental factors potentially influencing the abundance of toxigenic genotypes. Finally, toxigenic genotypes can be detected from single cells: single colonies or filaments of cyanobacteria (Dolichospermum (Anabaena) sp., Microcystis sp., Planktothrix sp.) can be identified according to morphological criteria during counting via microscopy and then analysed by PCR for their potential of toxin production.

\section{BOX 13.2: BENEFITS OF MOLECULAR TOOLS SUPPORTING THE MONITORING OF CYANOBACTERIA}

\section{EARLY WARNING}

Molecular tools can support the identification of waterbodies at risk for toxic bloom formation early on in the growing season, thus supporting an economically efficient selection of situations for cyanotoxin analysis. Using quantitative PCR (qPCR)-based methods, it is possible to quantify toxigenic cyanobacteria occurring rarely in the plankton community or in food supplements that otherwise might be overlooked by microscopical methods. 


\section{UNDERSTANDING ENVIRONMENTAL DRIVERS}

Early identification of toxigenic genotype occurrence may lead to a more detailed recording of environmental factors potentially influencing the abundance of toxigenic genotypes.

\section{IDENTIFYING TOXIGENIC CYANOBACTERIA}

Toxigenic cyanobacteria can be identified by sequencing of PCR-amplified indicative genes. Alternatively, single colonies of cyanobacteria are identified and taxonomically assigned by microscopical inspection according to morphological criteria and then analysed for toxigenic genotype occurrence.

In general, the application of molecular tools is possible either using biomass from isolated strains or isolated colonies/filaments grown in cultures or using biomass collected from field samples. The latter sample type will lead to rapid results on toxigenic cyanobacteria occurrence, however may contain a larger number of taxa carrying toxigenic genes which are not necessarily the dominant taxa in the respective sample (Rantala et al., 2006). Nevertheless, all sample types require a few mandatory steps, which include:

i. sampling of biomass or isolation of individual colonies/filaments under the microscope;

ii. extraction of the nucleic acid (DNA);

iii. amplification of gene fragments indicative of toxin synthesis based on conventional or quantitative PCR (qPCR);

iv. detection of PCR products using agarose gel electrophoresis (conventional PCR) or fluorescent dyes (qPCR or digital droplet PCR, ddPCR).

The sequencing of PCR products is optional and useful to confirm the results obtained or to identify the toxin-producing organism. More recent technology has enabled the so-called deep sequencing of PCR products which has become a widely applied technique to monitor the diversity of microorganisms and cyanobacteria in general (Pessi et al., 2016). The following gives an overview on the general workflow of applying molecular tools.

\subsection{Sampling and nucleic acid extraction}

In general, the basic sampling steps (e.g., stratified versus depth-integrated sampling, low vacuum filtration) are identical to the processing of samples for cyanotoxin detection and analysis (see Chapter 14). Food supplement 
samples should be handled as in food safety programmes for microbiological analysis (e.g., ISO, 2006).

However, molecular analyses require sampling precautions against crosscontamination or DNA degradation. For example, as all polymerase chain reaction (PCR)-based methods are highly sensitive (allowing to detect gene copies from single cells), the possibility of sample cross-contamination needs to be reduced as much as possible (e.g., by using new sample vessels or exhaustive rinsing of sample/filtration equipment between sampling dates or sites). Drying of biomass at high temperature (e.g., $100^{\circ} \mathrm{C}$ ) also should be avoided, as it leads to fragmentation of DNA. Similarly, nucleases released during cell lysis can lead to DNA fragmentation within a short time, and therefore, those enzymes need to be inactivated during the DNA extraction process. Typically, biomass for DNA extraction and subsequent PCR analysis is either used fresh or it has to been stored at $-20^{\circ} \mathrm{C}$.

The conventional DNA extraction procedure uses a combination of osmotic shock and enzymatic treatment followed by chemical phase separation (e.g., Franche \& Damerval, 1988). This DNA extraction procedure has been refined to obtain both qualitative and quantitative results, and today, robust protocols on cyanobacterial DNA extraction are available (e.g., Kurmayer et al., 2003). In some cases, extensive mucilage production as indicated by high viscosity of the DNA extract can inhibit the subsequent PCR amplification, and polysaccharides need to be selectively removed (Tillett \& Neilan, 2000). In general, conventional DNA isolation procedure protocols are more time-consuming but cheaper than extraction with easy-to-use commercial DNA isolation kits which are widely available. Kit-based techniques typically include anion-exchange columns for DNA binding and purification. However, it is important to validate the efficiency of such techniques before using them for monitoring (Schober et al., 2007). DNA extraction from food supplements can be more difficult as for this purpose, cyanobacteria typically are processed by drying, and food supplements may contain additives that can affect DNA extraction efficiency, for example, pharmaceutical bulking agents with adsorbent properties (Costa et al., 2015). Thus, purification of DNA or alternatively the addition of substances reducing the effect of PCR inhibitors might be routinely required (Ramos et al., 2017a; b). Individual cyanobacterial colonies or filaments can be selected for PCR amplification of genes under a stereo microscope using a forceps or a micropipette (Kurmayer et al., 2002). Colonies or filaments are picked randomly from a subsample containing a few specimen only, washed by serial transfers in standard solution and stored in PCR buffer in the freezer $\left(-20^{\circ} \mathrm{C}\right)$. The DNA is extracted most efficiently by short sonification (Chen et al., 2016), and the obtained DNA quantities are sufficient for multiple individual PCR experiments. 


\subsubsection{Polymerase chain reaction (PCR) methodology}

PCR is the technique that allows creating multiple copies of specific gene fragments through amplification by DNA polymerases. The most critical step for the reliable detection of toxigenic cyanobacteria is the selection of appropriate oligonucleotides (primers) which are used as molecular probes. Besides standard laboratory equipment, the instrumentation comprises a PCR cycling machine, a gel electrophoresis chamber and a gel documentation device. For detailed information on how to perform PCR, see the widely available laboratory manual revised by Sambrook and Russell (2001).

In contrast, quantitative PCR allows the determination of actual gene copy numbers (that can be used to approximate cell equivalents) and thus, by choosing the right targets for PCRs, the proportion of toxigenic genotypes present in a sample. In quantitative PCR (qPCR), amplification of the target gene is followed in real time via the detection of a fluorescent signal generated from DNA strand-intercalating dyes at each PCR cycle (e.g., SYBR Green). qPCR is based on the principle that the target DNA sequence is doubled in each cycle and that the dynamic increase of the recorded amplification reflects the amount of target sequence originally present. Theoretically, the more target sequence (or target genotypes) can be found in a specific sample, the earlier the amplification curve exceeds a predefined fluorescence threshold. The PCR cycle when this threshold is crossed is called a threshold cycle, $\mathrm{C}_{\mathrm{t}}$, or quantification cycle, $\mathrm{Cq}$ (-value). The use of fluorescent dyes makes qPCR most sensitive with calibration curves showing a wide dynamic range (up to seven orders of magnitude). Detailed information on the application of (q)PCR in the analysis of toxin genes has been compiled through the EU-initiative CyanoCOST (RantalaYlinen et al., 2017).

Digital droplet PCR (ddPCR) quantitates a target DNA sequence based on PCR of a partitioned DNA sample. The number of PCR-positive and PCR-negative partitions is used to determine the absolute number of target DNA molecules (Hindson et al., 2013). Reports on the use of ddPCR are only emerging, but first comparisons with qPCR revealed a comparable result (Te et al., 2015; Nshimyimana et al., 2019; Wood et al., 2019).

\subsubsection{Detection of toxigenic cyanobacteria}

Cyanotoxins are synthesised by large multifunctional enzyme complexes via the thiotemplate mechanism in a stepwise manner, known as nonribosomal peptide synthesis (NRPS). These NRPS enzyme complexes belong to the largest proteins within the prokaryotic cell (several thousand amino acids) and are often combined with polyketide synthases (PKS) (see Chapter 2; Dittmann et al., 2013). Large parts of gene sequences 
of particular biosynthesis gene clusters have been found to be variable and therefore not suitable for designing PCR primers with the desired specificity and sensitivity. For the microcystin $(m c y)$ and nodularin (nda) biosynthesis gene cluster, conserved gene regions have been identified in the $m c y E / n d a F$ gene encoding the enzymatic step condensing the Adda side chain with $\mathrm{D}$-glutamate forming the conserved core of the peptides (Rantala et al., 2004; Jungblut \& Neilan, 2006). With this region, PCR detection of microcystin and nodularin biosynthesis genes is possible in all cyanobacterial producers.

In contrast to microcystin synthesis, for the cylindrospermopsin synthesis (cyr) gene cluster, the cyrJ gene encoding a tailoring enzyme such as the sulfotransferase catalysing the sulphation of the C-12 atom of the cylindrospermopsin molecule was found only in cylindrospermopsin-producing strains (Mihali et al., 2008). However, the core genes encoding the synthesis of the cylindrospermopsin molecule itself, that is, cyrA/aoaA encoding the amidinotransferase or $c y r \mathrm{~B} / a o a \mathrm{~B}$ and $c y r \mathrm{C} / a o a \mathrm{C}$ encoding NRPS/PKS, were also detected in non-cylindrospermopsin-producing strains (Ballot et al., 2011; Hoff-Risseti et al., 2013) and thus are not considered reliable indicators. Thus, the cyrJ can be considered a gene marker to indicate potential cylindrospermopsin producers among the genera Dolichospermum, Aphanizomenon, Raphidiopsis (Cylindrospermopsis) and Oscillatoria (Mankiewicz-Boczek et al., 2012).

For saxitoxin biosynthesis, at the time of publication of this book, no gene loci are known that can unambiguously infer the $s x t$ gene cluster from a diagnostic polymerase chain reaction (PCR) (Ballot et al., 2010; Casero et al., 2014). Indeed, all genes tested have also been detected in a variety of cyanobacterial strains not producing saxitoxins. A protocol of several genes serves to indicate saxitoxin synthesis potential: sxtA encoding a PKS, s $x t G$ encoding an amidinotransferase, $s x t H$ encoding hydroxylation of the C-12 atom, sxtI encoding carbamoylation and sxtX encoding hydroxylation of the N-1 atom, (Casero et al., 2014). The elucidation of the saxitoxin biosynthesis genes has been started from identifying a gene encoding an O-carbamoyltransferase (Kellmann et al., 2008), now called sxtI, that has been proposed as a reliable marker to indicate saxitoxin synthesis (Ballot et al., 2016) but requires further confirmation.

For the detection of an anatoxin-a synthesis gene, a conserved region of anaC encoding an NRPS module for proline activation (an initiating step of anatoxin-a synthesis) has been identified and primers able to detect anaC in both Oscillatoria sp. and in Dolichospermum sp. as well as in Aphanizomenon sp. have been designed (Rantala-Ylinen et al., 2011). The encoded NRPS AnaC has been heterologously expressed and a specificity for proline as a substrate under in vitro conditions has been reported (Mejean et al., 2009), which also makes it a reliable marker for PCR-based monitoring and early warning. 
Notably PCR approaches can be combined with downstream applications such as direct sequencing of amplicons, or cloning and subsequent sequencing, or restriction fragment length polymorphism (RFLP) analysis. This type of post-PCR result analysis can inform about genera or species forming a particular toxigenic genotype. For example, Hisbergues et al. (2003) used a PCR-based detection technique for microcystin synthesis genes using $m c y A$ followed by differentiation of genera by RFLP of the obtained PCR product. Similarly, Rantala-Ylinen et al. (2011) used a PCRbased detection technique for anaC synthesis gene and the differentiation of toxigenic genera by RFLP of the obtained PCR product.

\subsubsection{Estimates of cyanobacterial biomass by molecular approaches}

By using reference genes (see above), it is possible to estimate total cyanobacterial biomass or biomass of particular cyanobacterial genera in a water sample. In general, qPCR assays have been used either for $16 \mathrm{~S}$ rDNA gene regions specific for cyanobacteria (Rinta-Kanto et al., 2005) or for gene loci specific for individual cyanobacterial genera known to produce cyanotoxins such as (i) the phycocyanin-intergenic spacer region (PC-IGS) for the genera Microcystis (Kurmayer \& Kutzenberger, 2003) and Planktothrix (Ostermaier \& Kurmayer, 2009; Kurmayer et al., 2011); (ii) the RNA polymerase gene loci rpoC for Raphidiopsis sp. (Fergusson \& Saint, 2003; Rasmussen et al., 2008) and Chrysosporum (Aphanizomenon) ovalisporum (Campo et al., 2013); or (iii) the $16 \mathrm{~S}$ rDNA for Microcystis sp. (Rinta-Kanto et al., 2005).

The molecular approach is an alternative to microscopic cell counting but has been primarily used to relate qPCR signals (Cq-values) indicative of cyanotoxin synthesis genes to the total cyanobacterial population, in order to quantify the proportion of a toxigenic subpopulation. For this purpose, it is required to compare Cq-values with microscopic cell counts. Standard curves need to be established (i) to quantify the target genotype using either cell numbers or gene copies and (ii) to determine the specificity and sensitivity of a specific quantitative PCR (qPCR) assay with isolates and background DNA (e.g., Kurmayer \& Kutzenberger 2003). A more detailed protocol on calibration of qPCR results is available in Kurmayer et al. (2017).

qPCR assays have also been developed to quantify cyanobacterial taxa potentially producing cyanotoxins, such as the genus Dolichospermum (Doblin et al., 2007) and the species Dolichospermum planktonicum (Rueckert et al., 2007). For all the taxa mentioned above, quantifying cell numbers or biovolume using QPCR gave similar results to those obtained by cell counts via microscopy. For the genera Microcystis, Planktothrix and Raphidiopsis, close correlations have been reported from field samples between qPCR estimates and cell counts ranging across several orders of magnitude (i.e., $10^{2}-10^{6}$ cells $/ \mathrm{mL}$ ). The limit of detection/quantification 
generally is in the range of a hundred to a few thousand cells per $\mathrm{mL}$ (Kurmayer \& Kutzenberger, 2003; Rasmussen et al., 2008; Chiu et al., 2017). However, for cyanobacterial taxa classified as polyphyletic, for example, the genera Aphanizomenon or Dolichospermum (see Chapter 3), the qPCR approach is less feasible because it would require to run many qPCRs to quantify multiple individual taxa of a genetically diverse genus for each individual sample. Further insights in the molecular phylogeny of cyanobacteria will provide the basis for developing qPCR assays for their quantification.

\subsubsection{Set up of PCR assays}

In general, the presence of toxin genes is tested in one PCR, while another independent reaction is used to confirm the presence of cyanobacteria as well as to check for the quality of the DNA (or the presence of potential PCR inhibitors). In many studies, $16 \mathrm{~S}$ ribosomal DNA (Taton et al., 2003) or gene loci encoding the synthesis of accessory pigments such as phycocyanin (cpcBA; Neilan, 1995) have been amplified, but not exclusively (Moreira et al., 2013). As a positive control for PCR, genomic DNA extracted from isolated strains should be used. A list of toxic strains containing the respective target genes, including information on their availability from international culture collections, is given in Kurmayer et al. (2017).

For the use of quantitative PCR (qPCR), the same principle has been applied to control for uncertainties in quantitative estimates of toxic genotypes, for example, due to a physiological variation of the gene or genome copy number (Kurmayer \& Kutzenberger, 2003). Typically, primers specified to amplify the total population (generally at genus level) as well as those genotypes that carry the cyanotoxin synthesis genes have been designed. Several qPCR assays have been developed to quantify microcystin/nodularin genes in a given volume of water (for reviews, see Kurmayer \& Christiansen (2009), Martins \& Vasconcelos (2009), Kim et al. (2013), Pacheco et al. (2016), and Rantala-Ylinen et al. (2017)). In particular, the Taq nuclease assay (TNA) has been used to quantify microcystin genotypes in water samples (Kurmayer \& Kutzenberger, 2003). This approach is based on the quantification of the total population of a specific cyanobacterium by a TNA targeted to the intergenic spacer region within the phycocyanin operon and another TNA targeted to the subpopulation carrying the mcy genes. A calibration curve based on defined cell concentrations or gene copy numbers is established by relating the known DNA concentrations to the threshold cycle of the diluted DNA extract. Similarly, qPCR assays have been developed for cylindrospermopsin synthesis genes (Rasmussen et al., 2008; Campo et al., 2013) and saxitoxin genes (Al-Tebrineh et al., 2010; Savela et al., 2015). For anatoxin synthesis genes, a qPCR approach was developed by Wang et al. (2015). For benthic cyanobacteria (Microcoleus 
(Phormidium) autumnalis), Kelly et al. (2018) developed a specific qPCR assay targeting the ana $\mathrm{C}$ gene.

Another option is to use multiplex PCR and to run two, three or four reactions in the same test tube (Saker et al., 2007; Al-Tebrineh et al., 2010). However, it is emphasised that multiplex (q)PCR requires substantial optimisation (because of competitive effects of primers and targets) and its use is not widespread (see Pacheco et al. (2016) for a review). Multiplex qPCR has been used in monitoring of Chrysosporum ovalisporum in Australia integrating three methods: (i) microscopical identification and enumeration, (ii) multiplex qPCR for $16 \mathrm{~S}$ rDNA, $m c y \mathrm{E}, c y r \mathrm{~A}$ and $s x t \mathrm{~A}$ gene quantification (iii) and toxin analysis by LC-MS (Crawford et al., 2017). Such integrated approaches may contribute to more efficient handling of high sample numbers from large surveys in future, allowing faster and more precise monitoring (e.g., Lu et al., 2019) to support risk assessment.

\subsubsection{Limits of PCR assays}

Microcystin synthesis gene clusters may be inactive due to various mutations, and positive polymerase chain reaction (PCR) results thus overestimate the potential of microcystin production in water (Nishizawa et al., 1999). Although cyanotoxin production typically is constitutive if individual strains are analysed (see Chapter 4), inactivation of microcystin synthesis genes occurs regularly under natural conditions (e.g., by transposable elements or partial deletions; Chen et al. (2016)). Thus, it is not surprising that the qPCR-based quantification of $m c y / n d a$ genes is not always quantitatively related to the analysed microcystin/nodularin concentrations in field samples (reviewed by Pacheco et al., 2016). By analysing 38 studies published in peer-reviewed journals, the authors nevertheless concluded that qPCR can be proposed as a predictor for microcystin/nodularin concentrations.

Less data are available for the other cyanotoxins such as cylindrospermopsin, for which correlations between cylindrospermopsin concentrations and qPCR results have been reported from field samples (Pacheco et al., 2016; Lei et al., 2019). Data for saxitoxin are yet more scarce, with correlations between qPCR data (e.g., sxtA gene copies) and saxitoxin concentrations quite limited (e.g., Savela et al., 2016), in part because the gene loci used are not unambiguously indicative of saxitoxin synthesis and also because of the variety of saxitoxins (section 2.4). For anatoxin synthesis, Wood and Puddick (2017) report gene copy numbers estimated by qPCR with statistically significant positive relationships to anatoxin-a contents of benthic cyanobacteria. Since there are multiple reasons for poor correlations and these cannot always be differentiated (Ostermaier \& Kurmayer, 2010), the current pragmatic approach in qPCR application as used by Pacheco et al. (2016) is to compare experience between research groups and waterbodies around the globe to improve molecular monitoring approaches. 
An inherent limit of the accuracy of quantification in all qPCR-based techniques is the semilogarithmic nature of the calibration curves which potentially leads to overestimation or underestimation, respectively, by up to $70 \%$ (Schober et al., 2007) in estimating genotype numbers or proportions, because minor deviations on linear scale (Cq-values) are translated into larger deviations on logarithmic scale (DNA amount in the template). As a rule of thumb, deviations of $<0.5$ in Cq-value are considered due to experimental noise. This unspecific variation must be taken into account when translating the results from Cq-values into absolute numbers.

\subsubsection{Sequencing of PCR products}

Today DNA sequencing facilities offer rapid services at costs ranging at less than $2 €$ per sequence of approximately 800 base pairs as of 2020. Single PCR products obtained from isolated strains are sequenced directly using the conventional Sanger chain termination method allowing confirmation of the specificity of the obtained PCR products and identification of the source organism. PCR products obtained from field samples often contain mixtures of PCR fragments originating from various genotypes. Separating the individual genotypes requires a cloning approach before sequencing according to standard techniques (Sambrook \& Russell, 2001). So-called cloning kits with cloning vectors (plasmids) are commercially available and allow for the amplification of individual genotypes. As a last step, vectors carrying the inserted sequence of individual genotypes are introduced into Escherichia coli, purified and sequenced.

\subsubsection{Application of PCR-based methods in monitoring}

In principle, PCR-based assays have the potential to guide a more efficient application of chemical-analytical tools. For example, toxigenicity (microcystin synthesis) has been detected in cyanobacterial food supplements and has been confirmed using ELISA techniques (Saker et al., 2005). The sequencing of the obtained PCR products revealed the occurrence of Microcystis aeruginosa in minor proportion, while the dominant organism Aphanizomenon flosaquae was found nontoxic. Similarly, Vichi et al. (2012) used an approach combining PCR-based tools with chemical-analytical detection to analyse cyanotoxins in food supplements from the Italian market and to identify the contaminating organisms. While $M$. aeruginosa was identified in A. flosaquae products, the contamination with $M$. aeruginosa was surprisingly, albeit less frequently, also confirmed from products derived from "Spirulina" cultivated at high $\mathrm{pH}$ and salt concentrations. A further application is the quality control of commonly used open 
pond mass cultures of eukaryotic microalgae food supplement production for contamination caused by cyanobacteria (Görs et al., 2010).

Analogously for environmental samples, PCR-based methods have been applied frequently to identify the various cyanotoxin (microcystin)-producing organisms. For example, in the temperate climatic zone, microcystinproducing genera such as Microcystis, Planktothrix and Dolichospermum frequently co-occur and diagnostic PCR has been used to differentiate and quantify the proportion of respective toxigenic genera (Rantala et al., 2006). Similarly, in tropical lakes in East Africa, PCR of $m c y$ genes followed by sequencing showed that Microcystis was the dominant microcystin-producing genus, while co-occurring Dolichospermum sp. and Planktothrix sp. were not found to be toxigenic (Okello et al., 2010). Furthermore, the PCR-based analyses can give important clues on the stability or variability of the genetic structure of toxigenic subpopulations in aquatic habitats. For example, in lakes of the Alps, the changes occurring in toxigenicity of Planktothrix populations were observed to happen rather slowly over a period of three decades with nontoxic genotypes only showing a slow increase in proportion (Ostermaier et al., 2013). In the monitoring of Polish waterbodies, PCR methods have been routinely applied and qPCR results have been used to explain variable microcystin contents in Microcystis sp. biomass (Gagała et al., 2014). In conclusion, despite their limitations in absolute quantification, PCR-based methods might well increase the predictability of toxin concentrations by increasing the information on source organisms over time and space.

\subsubsection{Identifying toxigenic cyanobacteria using high-throughput sequencing}

The PCR-based tools described above cannot give comprehensive information on the taxonomic composition of cyanobacterial communities potentially including toxigenic species. In analogy to microscopy-based counting of cells (see section 13.3.1), the more recently developed deep amplicon (high-throughput) sequencing is able to sequence a very large number of PCR amplicons simultaneously and has been proposed as a tool for monitoring cyanobacteria in the environment (Eldridge et al., 2017). By obtaining at least several thousands of sequences from one amplified gene locus per sample (e.g., $16 \mathrm{~S}$ rRNA), it is possible to monitor the presence of phytoplankton taxa and including bacteria, possibly including less abundant potentially toxigenic species. In general, the PCR products obtained using universal primers are barcoded via ligation of short nucleotides (MIDs, multiplex identifiers), clonally amplified (e.g., by the so-called bridge amplification of Illumina) and sequenced in parallel on plates. The large amount of sequence reads obtained requires bioinformatical processing following established standard algorithms 
and taxonomic reference databases available through various publically available international platforms, that is, the Ribosomal Database Project (Cole et al., 2013), or the "Greengenes" application, (DeSantis et al., 2006 (McDonald et al., 2012)) or the SILVA database (Glöckner et al., 2017). Further, several standard sequence-processing pipelines have been designed (e.g., (Schloss et al., 2009; Caporaso et al., 2010; Albanese et al., 2015; Bolyen et al., 2019). In general, the bioinformatics steps include (i) the quality trimming of sequences regarding the exact match of the MID code and the primer, the minimum length in base pairs, the frequency of ambiguous nucleotides in a sequence read, as well as chimera detection; (ii) the clustering of sequences by the genetic distance and assigning to operational taxonomic units (OTUs). Typically, for rDNA genes, a 3\% genetic distance threshold is defined and OTUs will then be assigned taxonomically using reference databases as cited above; (iii) the calculation of rarefaction curves which are used to estimate additional sequencing effort as well as to standardise the comparison of diversity and richness estimates between samples; (iv) the calculation of diversity indices as well as richness estimators from the frequency of the OTUs and (v) the use of multivariate statistics to explain the variability in the data sets from recorded metadata (Deng et al., 2017).

Deep-sequencing application might be of relevance for monitoring of invasive species with toxigenic potential, for example, Raphidiopsis raciborskii or Nodularia spumigena (Sukenik et al., 2015). Currently, the reference taxonomic databases such as RDP have a relatively low resolution (Cole et al., 2013) and individual species of cyanobacteria are only rarely resolved. The relatively short read length $(<400 \mathrm{bp})$ might be one cause of the low percentage of resolved OTUs, as environmental samples may contain a high share of OTUs which have not been characterised previously (Albanese et al., 2015). Further comparing resolved OTUs with the adjusted OTU composition in artificial communities can reveal a technical bias (Pessi et al., 2016). Comparing microscopical data with data obtained from deep sequencing also reveals discrepancies which show not only the limitation of microscopy (i.e., underestimating the abundance and diversity of picocyanobacteria such as Synechococcus), but also the limitation in deep sequencing, for example, because of low or uncertain resolution (Eiler et al., 2013; Xiao et al., 2014). In future, it will be important to standardise these emerging techniques (Hornung et al., 2019) to avoid systematic bias (Boers et al., 2016), for example, by using artificial (mock) communities (Pessi et al., 2016) as well as to create taxonomic reference databases from sequenced and morphologically described strains. Alternatively, as a way forward, the information obtained from both methodologies, microscopy and deep sequencing is combined and integrated into the community analysis of environmental samples. 


\section{I3.7 DETERMINATION OF NUTRIENT CONCENTRATIONS}

As discussed in detail in Chapter 4, the capacity for development of a cyanobacterial bloom depends on the available concentrations of nutrients, primarily of phosphorus and nitrogen. In freshwaters, often phosphorus concentrations limit the amount of biomass that can form in a given waterbody, but sometimes nitrogen is limiting. The chief sources of nitrogen are nitrate and ammonium, but to some extent, their lack can be compensated by some cyanobacteria through fixation of atmospheric nitrogen. Thus, even if phosphate is clearly the factor limiting carrying capacity, knowledge of nitrogen availability helps to predict whether nitrogen-fixing species are likely to dominate.

Cyanobacterial cells can store only some excess nitrogen, but can store phosphorus for up to four cell divisions, enabling a single cell to multiply into 16 cells without the need to take up further phosphorus. Information on dissolved phosphorus concentrations therefore only demonstrates that, if it can be detected, the phytoplankton population is not currently limited by phosphorus availability. In order to assess the capacity of the waterbody to support a cyanobacterial population, total phosphorus (TP) is a much better predictor. To assess whether nitrogen may be limiting, analysis of dissolved components (chiefly nitrate and ammonium) is sufficient.

In modern laboratories, various fractions of nitrogen and phosphorus are today quantified by automated technologies that allow high-throughput analyses generally based on photometry such as flow injection analysis (FIA) or continuous flow analysis (CFA). Respective, standard methods are available for nitrite and nitrate (ISO, 1996), ammonium (ISO, 2005), and total and ortho-phosphate (ISO, 2003). Since FIA or CFA is not available to many laboratories, simpler and largely manual methods for nutrient analysis are still in use. In the following, a brief description of such methods is given together with requirements to perform analyses.

Before any analysis is to be implemented in a laboratory, the national and international regulations concerning laboratory safety and environmental protection must be consulted and duly considered. Any laboratory analysis requires trained laboratory staff, especially when handling toxic or otherwise harmful chemicals is part of it.

Among the methods available, the procedure of Hansen and Koroleff (2007) for determining TP has proved to be most reliable and is the basis of an ISO protocol. For nitrate and ammonium, several methods are available, and the ISO method with the least demands on equipment is described below. For details on ISO methods, see the International Organization for Standardization's website (https://www.iso.org/). 


\subsection{Analysis of phosphorus}

Phosphorus in various types of waters can be determined spectrometrically by the digestion of organic phosphorus compounds to inorganic soluble reactive phosphorus (SRP, largely comprising ortho-phosphate) and transforming this to an antimony-phosphomolybdate complex under acidic conditions, which is then reduced to a strongly coloured blue molybdenum complex. The internationally harmonised method as described in ISO (2004) is applicable to many types of waters (surface-, ground-, sea- and wastewater) in a concentration range of $0.005-0.8 \mathrm{mg} / \mathrm{L}$. Differentiation by the following fractions is possible through filtration procedures:

- $S R P$ : filtered sample, generally with a pore size of $0.45 \mu \mathrm{m}$.

- Dissolved organic phosphorus (DOP): digested filtered sample; dissolved organic P is converted into SRP.

- TP: digested unfiltered sample; all organic P is converted to SRP.

- Particulate phosphorus (PP): difference between TP and DOP.

For SRP sample preparation, it is important to note that filters can release phosphorus. To avoid a bias, the filters must be washed with the water sample $(10-25 \mathrm{~mL})$ and this filtrate be discarded.

Digestion or mineralisation of organophosphorus compounds to SRP for DOP and TP analysis is performed in tightly sealed screw-cap vessels with persulphate, under pressure and heat in an autoclave (or a household steamer), or simply by gentle boiling. The following gives an overview of the procedure, necessary equipment and chemicals; for details, see ISO (2004).

\section{Equipment}

- Photometer measuring absorbance in the visible and near-infrared spectrum above $700 \mathrm{~nm}$; sensitivity is optimal at $880 \mathrm{~nm}$; sensitivity is increased if optical cells of $50 \mathrm{~mm}$ optical pathlength are used

- Filter assembly and membrane filters, $45 \mathrm{~mm}$ diameter with $0.45 \mu \mathrm{m}$ pore size

- For the digestion of samples (TP and DOP), an autoclave (or steamer) suitable for $115-120^{\circ} \mathrm{C}$

- For the digestion of samples, borosilicate vessels with heat-resistant caps that can be tightly sealed

- Bottles for samples as described in Chapter 14

- Precleaned glass bottles for filtered samples

\subsubsection{Analysis of nitrate}

Several methods for the determination of nitrate have been provided by the ISO, the simplest being a spectrometric measurement of the yellow 
compound formed by the reaction of sulphosalicylic acid with nitrate and subsequent treatment with alkali (ISO, 1988). The equipment required is a spectrometer operating at a wavelength of $415 \mathrm{~nm}$ and cuvettes with an optical path length of $40-50 \mathrm{~mm}$, evaporating dishes, a water bath capable of accepting six or more dishes and a water bath capable of thermostatic regulation to $25^{\circ} \mathrm{C}$. This method is suitable for surface and potable water samples and has a detection limit of $0.003-0.013 \mathrm{mg} / \mathrm{L}$ (depending on optical equipment). Interference from a range of substances, particularly chloride, orthophosphate, magnesium and manganese (III), is possible. Interference problems can be avoided with other spectrometric methods (ISO, 1986b; c).

The equipment is similar to the one required for phosphorus analysis.

\subsubsection{Analysis of ammonium}

A manual spectrometric method is given in ISO (1984b), which analyses a blue compound formed by the reaction of ammonium with salicylate and hypochlorite ions in the presence of sodium nitrosopentacyanoferrate (III) at a limit of detection of $0.003-0.008 \mathrm{mg} / \mathrm{L}$. An automated procedure is given in ISO (1986a). A distillation and titration method is given in ISO (1984a).

The equipment is similar to the one required for phosphorus analysis.

\subsubsection{On-site analysis techniques for nutrients}

A number of technologies are available for rapid on-site analysis of primarily dissolved nutrients such as SRP, nitrate and ammonium.

Most simple with respect to handling and required equipment are test strips that are submerged in (filtered) water and after a short incubation time, a colour change allows to estimate the concentration. Expectedly, the sensitivity is comparatively low as is the accuracy, but in some occasions, a rapid semiquantitative result may be more valuable than more accurate results that are available only after a considerable delay.

Selective electrodes are available for nitrate and ammonium (Cuartero \& Bakker, 2017). Handling and data-logging is similar to that for $\mathrm{pH}$ or oxygen electrodes. This technique may be interesting in particular when a high variability of concentrations is suspected, for example, in individual inflows to a reservoir.

For on-site analyses, also fully functional photometers and ready-to-use reagents kits are available. Digestion of samples for analysis of total phosphorus is also possible on-site.

On-site analyses are generally less accurate and less sensitive compared to laboratory analyses but are, on the other hand, less expensive and faster with respect to time to result. This needs to be balanced for individual monitoring programmes. Preferably, any method eventually adopted is evaluated for accuracy and sensitivity by testing an individual sample with different methods. 


\section{REFERENCES}

Al-Tebrineh J, Mihali TK, Pomati F, Neilan BA (2010). Detection of saxitoxinproducing cyanobacteria and Anabaena circinalis in environmental water blooms by quantitative PCR. Appl Environ Microbiol. 76:7836-7842.

Albanese D, Fontana P, De Filippo C, Cavalieri D, Donati C (2015). MICCA: a complete and accurate software for taxonomic profiling of metagenomic data. Sci Rep. 5:9743.

Alcántara I, Piccini C, Segura A, Deus S, González C, de la Escalera GM et al. (2018). Improved biovolume estimation of Microcystis aeruginosa colonies: A statistical approach. J Microbiol Methods. 151:20-27.

Anagnostidis K, Komárek J (1985). Modern approach to the classification system of Cyanophytes. 1-Introduction. Arch Hydrobiol Algol Stud. 38-39:291-302.

Anagnostidis K, Komárek J (1988). Modern approach to the classification system of Cyanophytes 3- Oscillatoriales. Arch Hydrobiol Algol Stud 80 (50-53):327-472.

Anagnostidis K, Komárek J (1990). Modern approach to the classification system of Cyanophytes. 5-Stigonematales. Arch Hydrobiol 86, Suppl:1-73.

Asai R, Horiguchi Y, Yoshida A, McNiven S, Tahira P, Ikebukuro K et al. (2001). Detection of phycobilin pigments and their seasonal change in Lake Kasumigaura using a sensitive in situ fluorometric sensor. Anal Lett. 34:2521-2533.

Ballantine D (1953). Comparison of the different methods of estimating nanoplankton. J Mar Biol Assoc UK. 32:129-147.

Ballot A, Cerasino L, Hostyeva V, Cirés S (2016). Variability in the sxt gene clusters of PSP toxin producing Aphanizomenon gracile strains from Norway, Spain, Germany and North America. PLoS One. 11:e0167552.

Ballot A, Fastner J, Wiedner C (2010). Paralytic shellfish poisoning toxin-producing cyanobacterium Aphanizomenon gracile in Northeast Germany. Appl Environ Microbiol. 76:1173-1180.

Ballot A, Ramm J, Rundberget T, Kaplan-Levy RN, Hadas O, Sukenik A et al. (2011). Occurrence of non-cylindrospermopsin-producing Aphanizomenon ovalisporum and Anabaena bergii in Lake Kinneret (Israel). J Plankton Res. 33:1736-1746.

Benfield MC, Grosjean P, Culverhouse PF, Irigoien X, Sieracki ME, Lopez-Urrutia A et al. (2007). RAPID: research on automated plankton identification. Oceanography. 20:172-187.

Bertani I, Steger CE, Obenour DR, Fahnenstiel GL, Bridgeman TB, Johengen $\mathrm{TH}$ et al. (2017). Tracking cyanobacteria blooms: Do different monitoring approaches tell the same story? Sci Tot Environ. 575:294-308.

Bertone E, Burford MA, Hamilton DP (2018). Fluorescence probes for real-time remote cyanobacteria monitoring: A review of challenges and opportunities. Water Res. 141:152-162.

Beutler M, Wiltshire KH, Meyer B, Moldaenke C, Luring C, Meyerhofer M et al. (2002). A fluorometric method for the differentiation of algal populations in vivo and in situ. Photosynth Res. 72:39-53.

Bidigare RR, Van Heukelem L, Trees CC (2005). Analysis of algal pigments by highperformance liquid chromatography. New York: Algal Culturing Techniques Academic Press:327-345. 
Boers SA, Jansen R, Hays JP (2016). Suddenly everyone is a microbiota specialist. Clin Microbiol Infect 22:581-582.

Bolyen E, Rideout JR, Dillon MR, Bokulich NA, Abnet CC, Al-Ghalith GA et al. (2019). Reproducible, interactive, scalable and extensible microbiome data science using QIIME 2. Nat Biotechnol. 37:852-857.

Box J (1981). Enumeration of cell concentrations in suspensions of colonial freshwater microalgae, with particular reference to Microcystis aeruginosa. Brit Phycol J. 16:153-164.

Brentrup JA, Williamson CE, Colom-Montero W, Eckert W, de Eyto E, Grossart HP et al. (2016). The potential of high-frequency profiling to assess vertical and seasonal patterns of phytoplankton dynamics in lakes: an extension of the Plankton Ecology Group (PEG) model. Inland Waters. 6:565-580.

Brophy MJ, Trueman BF, Park Y, Betts RA, Gagnon GA (2018). Fluorescence spectra predict microcystin-LR and disinfection byproduct formation potential in lake water. Environ Sci Technol. 53:586-594.

Brown NM, Mueller RS, Shepardson JW, Landry ZC, Morré JT, Maier CS et al. (2016). Structural and functional analysis of the finished genome of the recently isolated toxic Anabaena sp. WA102. BMC Genomics. 17:457.

Burnham JC, Stetak T, Boulger J (1973). An improved method of cell enumeration for filamentous algae and bacteria. J Phycol. 9:346-349.

Calteau A, Fewer DP, Latifi A, Coursin T, Laurent T, Jokela J et al. (2014). Phylumwide comparative genomics unravel the diversity of secondary metabolism in Cyanobacteria. BMC Genomics. 15:977.

Campo E, Lezcano M, Agha R, Cirés S, Quesada A, El-Shehawy R (2013). First TaqMan assay to identify and quantify the cylindrospermopsin-producing cyanobacterium Aphanizomenon ovalisporum in water. Adv Microbiol. 3:430-437.

Caporaso JG, Kuczynski J, Stombaugh J, Bittinger K, Bushman FD, Costello EK et al. (2010). QIIME allows analysis of high-throughput community sequencing data. Nat Meth. 7:335-336.

Casero MC, Ballot A, Agha R, Quesada A, Cirés S (2014). Characterization of saxitoxin production and release and phylogeny of sxt genes in paralytic shellfish poisoning toxin-producing Aphanizomenon gracile. Harmful Algae. $37: 28-37$.

Catherine A, Maloufi S, Congestri R, Viaggiu E, Pilkaityte R (2017). Cyanobacterial samples: preservation, enumeration, and biovolume measurements. In: Meriluoto J, Spoof L, Codd GA et al., editors: Handbook of cyanobacterial monitoring and cyanotoxin analysis. Chichester: John Wiley \& Sons. $313-330$.

CEN (2006). EN 15204: water quality - guidance standard on the enumeration of phytoplankton using inverted microscopy (Utermöhl technique). Brussels: European Committee for Standardization:46 pp.

CEN (2015). EN 16695: Water Quality - Guidance on the estimation of phytoplankton biovolume. Brussels, BE: European Committee for Standardization:40 pp.

Chen Q, Christiansen G, Deng L, Kurmayer R (2016). Emergence of nontoxic mutants as revealed by single filament analysis in bloom-forming cyanobacteria of the genus Planktothrix. BMC Microbiol 16:23. 
Chiu Y-T, Chen Y-H, Wang T-S, Yen H-K, Lin T-F (2017). A qPCR-based tool to diagnose the presence of harmful cyanobacteria and cyanotoxins in drinking water sources. Int J Environ Res Public Health. 14:547.

Choo F, Zamyadi A, Stuetz R, Newcombe G, Newton K, Henderson R (2019). Enhanced real-time cyanobacterial fluorescence monitoring through chlorophyll- $a$ interference compensation corrections. Water Res. 148:86-96.

Christiansen G, Fastner J, Erhard M, Börner T, Dittmann E (2003). Microcystin biosynthesis in Planktothrix: Genes, evolution, and manipulation. J Bacteriol. 185:564-572.

Cole JR, Wang Q, Fish JA, Chai B, McGarrell DM, Sun Y et al. (2013). Ribosomal Database Project: data and tools for high throughput rRNA analysis. Nucleic Acids Res. 42:D633-D642.

Costa J, Amaral JS, Fernandes TJ, Batista A, Oliveira MBP, Mafra I (2015). DNA extraction from plant food supplements: Influence of different pharmaceutical excipients. Mol Cell Probes. 29:473-478.

Crawford A, Holliday J, Merrick C, Brayan J, van Asten M, Bowling L (2017). Use of three monitoring approaches to manage a major Chrysosporum ovalisporum bloom in the Murray River, Australia, 2016. Environ Monit Assess. 189:202.

Cuartero M, Bakker E (2017). Environmental water analysis with membrane electrodes. Curr Opin Electrochem. 3:97-105.

Deng L, Sweetlove M, Blank S, Obbels D, Verleyen E, Vyverman W et al. (2017). Monitoring of toxigenic cyanobacteria using next-generation sequencing techniques. In: Kurmayer R, Sivonen K, Wilmotte A, Salmaso N, editors: Molecular tools for the detection and quantification of toxigenic Chichester: John Wiley \& Sons:277-299.

DeSantis TZ, Hugenholtz P, Larsen N, Rojas M, Brodie EL, Keller K et al. (2006). Greengenes, a chimera-checked $16 \mathrm{~S}$ rRNA gene database and workbench compatible with ARB. Appl Environ Microbiol. 72:5069-5072.

Desiderio RA, Moore C, Lantz C, Cowles TJ (1997). Multiple excitation fluorometer for in situ oceanographic applications. Appl Opt. 36:1289-1296.

Dittmann E, Fewer DP, Neilan BA (2013). Cyanobacterial toxins: biosynthetic routes and evolutionary roots. FEMS Microbiol Rev. 37:23-43.

Doblin MA, Coyne KJ, Rinta-Kanto JM, Wilhelm SW, Dobbs FC (2007). Dynamics and short-term survival of toxic cyanobacteria species in ballast water from NOBOB vessels transiting the Great Lakes - implications for HAB invasions. Harmful Algae. 6:519-530.

Edler L, Elbrächter M (2010). The Utermöhl method for quantitative phytoplankton analysis. In: Karlson B, Cusack C, Bresnan E, editors: Microscopic and molecular methods for quantitative phytoplankton analysis. Paris: Intergovernmental Oceanographic Commission of UNESCO:13-20.

Edwards DJ, Gerwick WH (2004). Lyngbyatoxin biosynthesis: Sequence of biosynthetic gene cluster and identification of a novel aromatic prenyltransferase. J Am Chem Soc. 126:11432-11433.

Eiler A, Drakare S, Bertilsson S, Pernthaler J, Peura S, Rofner C et al. (2013). Unveiling distribution patterns of freshwater phytoplankton by a next generation sequencing based approach. PLoS One. 8:e53516. 
Eldridge SLC, Driscoll C, Dreher TW (2017). Using high-throughput DNA sequencing, genetic fingerprinting, and quantitative PCR as tools for monitoring bloom-forming and toxigenic cyanobacteria in Upper Klamath Lake, Oregon, 2013 and 2014. US Geological Survey.

Fergusson KM, Saint CP (2003). Multiplex PCR assay for Cylindrospermopsis raciborskii and cylindrospermopsin-producing cyanobacteria. Environ Toxicol. 18:120-125.

Fernandez-Diaz JC, Glennie CL, Carter WE, Shrestha RL, Sartori MP, Singhania A et al. (2014). Early results of simultaneous terrain and shallow water bathymetry mapping using a single-wavelength airborne LiDAR sensor. IEEE J. 7:623-635.

Fewer DP, Wahlsten M, Österholm J, Jokela J, Rouhiainen L, Kaasalainen U et al. (2013) The genetic basis for $\mathrm{O}$-acetylation of the microcystin toxin in cyanobacteria. Chem Biol. 20:861-869.

Franche C, Damerval T (1988). Tests on nif probes and DNA hybridizations. Meth Enzymol. 167:803-808.

Friedrichs A, Busch J, van der Woerd H, Zielinski O (2017). SmartFluo: a method and affordable adapter to measure chlorophyll $a$ fluorescence with smartphones. Sensors. 17:678.

Gaggała I, Izydorczyk K, Jurczak T, Pawełczyk J, Dziadek J, Wojtal-Frankiewicz A et al. (2014). Role of environmental factors and toxic genotypes in the regulation of microcystins-producing cyanobacterial blooms. Microb Ecol. 67:465-479.

Giardino C, Bresciani M, Valentini E, Gasperini L, Bolpagni R, Brando VE (2015). Airborne hyperspectral data to assess suspended particulate matter and aquatic vegetation in a shallow and turbid lake. Rem Sens Environ. 157:48-57.

Glöckner FO, Yilmaz P, Quast C, Gerken J, Beccati A, Ciuprina A et al. (2017). 25 years of serving the community with ribosomal RNA gene reference databases and tools. J Biotechnol. 261:169-176.

Goddard VJ, Baker AC, Davy JE, Adams DG, De Ville MM, Thackeray SJ et al. (2005). Temporal distribution of viruses, bacteria and phytoplankton throughout the water column in a freshwater hypereutrophic lake. Aquat Microb Ecol. 39:211-223.

Görs M, Schumann R, Hepperle D, Karsten U (2010). Quality analysis of commercial Chlorella products used as dietary supplement in human nutrition. J Appl Phycol. 22:265-276.

Gregor J, Geris R, Maršálek B, Hetesa J, Marvan P (2005). In situ quantification of phytoplankton in reservoirs using a submersible spectrofluorometer. Hydrobiologia. 548:141-151.

Gregor J, Maršálek B (2004). Freshwater phytoplankton quantification by chlorophyll $a$ : a comparative study of in vitro, in vivo and in situ methods. Water Res. 38:517-522.

Gregor J, Maršálek B, Sipkova H (2007). Detection and estimation of potentially toxic cyanobacteria in raw water at the drinking water treatment plant by in vivo fluorescence method. Water Res. 41:228-234.

Hansen HP, Koroleff F (2007). Determination of nutrients. In: Grasshoff K, Kremling K, Ehrhardt $\mathrm{M}$ et al., editors: Methods of seawater analysis, third edition. Weinheim: Wiley-VCH:159-228. 
Hawkins PR, Holliday J, Kathuria A, Bowling L (2005). Change in cyanobacterial biovolume due to preservation by Lugol's Iodine. Harmful Algae. 4:1033-1043.

Hillebrand H, Dürselen C, Kirschtel D, Pollingher U, Zohary T (1999). Biovolume calculation for pelagic and benthic microalgae. J Phycol. 35:403-424.

Hindson CM, Chevillet JR, Briggs HA, Gallichotte EN, Ruf IK, Hindson BJ et al. (2013). Absolute quantification by droplet digital PCR versus analog realtime PCR. Nat Meth. 10:1003-1005.

Hisbergues M, Christiansen G, Rouhiainen L, Sivonen K, Börner T (2003). PCRbased identification of microcystin-producing genotypes of different cyanobacterial genera. Arch Microbiol. 180:402-410.

Hodges CM, Wood SA, Puddick J, McBride CG, Hamilton DP (2018). Sensor manufacturer, temperature, and cyanobacteria morphology affect phycocyanin fluorescence measurements. Environ Sci Pollut Res. 25:1079-1088.

Hoff-Risseti C, Dörr FA, Schaker PDC, Pinto E, Werner VR, Fiore MF (2013). Cylindrospermopsin and saxitoxin synthetase genes in Cylindrospermopsis raciborskii strains from Brazilian freshwater. PLoS One. 8:e74238.

Holm-Hansen O, Lorenzen CJ, Holmes RW, Strickland JD (1965). Fluorometric determination of chlorophyll. ICES J Mar Sci. 30:3-15.

Hornung BV, Zwittink RD, Kuijper EJ (2019). Issues and current standards of controls in microbiome research. FEMS Microbiol Ecol 95:fiz045.

Hötzel G, Croome R (1999). A phytoplankton methods manual for Australian freshwaters. Canberrra: Land and Water Resources Research and Development Corporation:58 pp.

ISO (1984a). ISO 5664. Determination of ammonium. Distillation and titration method. Geneva: International Organization for Standardization.

ISO (1984b). ISO 7150-1. Determination of ammonium Part 1: manual spectrometric method. Geneva: International Organization for Standardization.

ISO (1986a). ISO 7150-2. Determination of ammonium Part 2: automated spectrometric method. Geneva: International Organization for Standardization.

ISO (1986b). ISO 7890-1. Determination of nitrate Part 1:2,6-Dimethylphenol spectrometric method. Geneva: International Organization for Standardization.

ISO (1986c). ISO 7890-2. Determination of nitrate Part 2: 4-Fluorophenol spectrometric method after distillation. Geneva: International Organization for Standardization.

ISO (1988). ISO 7890-3. Determination of nitrate Part 3: spectrometric method using sulfosalicylic acid. Geneva: International Organization for Standardization.

ISO (1992). ISO 10260. Measurement of biochemical parameters. Spectrometric determination of the chlorophyll-a concentrations. Geneva: International Organization for Standardization.

ISO (1996). ISO 13395. Determination of nitrite nitrogen and nitrate nitrogen and the sum of both by flow analysis (CFA and FIA) and spectrometric detection. Geneva: International Organization for Standardization.

ISO (2003). ISO 15681-2. Determination of orthophosphate and total phosphorus contents by flow analysis (FIA and CFA) Part 2: method by continuous flow analysis (CFA). Geneva: International Organization for Standardization.

ISO (2004). ISO 6878. Determination of phosphorus. Ammonium molybdate spectrometric method. Geneva: International Organization for Standardization. 
ISO (2005). ISO 11732. Determination of ammonium nitrogen: method by flow analysis (CFA and FIA) and spectrometric detection. Geneva: International Organization for Standardization.

ISO (2006). ISO 20837. Microbiology of food and animal feeding stuffs Polymerase chain reaction (PCR) for the detection of food-borne pathogens - Requirements for sample preparation for qualitative detection. ISO 20837. Geneva: International Organization for Standardization.

Izydorczyk K, Tarczynska M, Jurczak T, Mrowczynski J, Zalewski M (2005). Measurement of phycocyanin fluorescence as an online early warning system for cyanobacteria in reservoir intake water. Environ Toxicol 20:425-430.

Jacobsen $\mathrm{T}$ (1978). A quantitative method for the separation of chlorophylls a and $\mathrm{b}$ from phytoplankton pigments by high pressure liquid chromatography. Mar Sci Commun. 4:33-47.

Jiang Y, Song G, Pan Q, Yang Y, Li R (2015). Identification of genes for anatoxin-a biosynthesis in Cuspidothrix issatschenkoi. Harmful Algae. 46:43-48.

Jiang Y, Xiao P, Yu G, Shao J, Liu D, Azevedo SM et al. (2014). Sporadic distribution and distinctive variations of cylindrospermopsin genes in cyanobacterial strains and environmental samples from Chinese freshwater bodies. Appl Environ Microbiol. 80:5219-5230.

Jungblut A-D, Neilan BA (2006). Molecular identification and evolution of the cyclic peptide hepatotoxins, microcystin and nodularin, synthetase genes in three orders of cyanobacteria. Arch Microbiol. 185:107-114.

Kahru M, Brown CW (1997). Monitoring of algal blooms: New techniques for detecting large-scale environmental change. Berlin: Springer:190 pp.

Karlson B, Cusack C, Bresnan E (2010). Microscopic and molecular methods for quantitative phytoplankton analysis. Paris, FRA: Intergovernmental Oceanographic Commission of UNESCO:110 pp. http://hab.ioc-unesco.org/ index.php?option=com_oe\&task=viewDocumentRecord\&docID=5440.

Kasprzak P, Padisák J, Koschel R, Krienitz L, Gervais F (2008). Chlorophyll a concentration across a trophic gradient of lakes: An estimator of phytoplankton biomass? Limnologica. 38:327-338.

Kaštovský J, Hauer T, Mareš J, Krautová M, Bešta T, Komárek J et al. (2010). A review of the alien and expansive species of freshwater cyanobacteria and algae in the Czech Republic. Biol Invasions. 12:3599-3625.

Kellmann R, Michali TK, Neilan BA (2008). Identification of a saxitoxin biosynthesis gene with a history of frequent horizontal gene transfers. J Mol Evol. 67:526-538.

Kelly LT, Wood SA, McAllister TG, Ryan KG (2018). Development and application of a quantitative PCR assay to assess genotype dynamics and anatoxin content in Microcoleus autumnalis-dominated mats. Toxins. 10:431.

Kim J, Lim J, Lee C (2013). Quantitative real-time PCR approaches for microbial community studies in wastewater treatment systems: applications and considerations. Biotechnol Adv. 31:1358-1373.

Komárek J (1991). A review of water-bloom forming Microcystis species, with regard to populations from Japan. Arch Hydrobiol Algol Stud. 64:115-127.

Komárek J (1996). Towards a combined approach for the taxonomy and species delimitation of picoplanktic cyanoprokaryotes. Arch Hydrobiol Algol Stud:377-401. 
Komárek J (2003). Planktic oscillatorialean cyanoprokaryotes (short review according to combined phenotype and molecular aspects). Hydrobiologia. 502:367-382.

Komárek J (2010). Modern taxonomic revision of planktic nostocacean cyanobacteria: a short review of genera. Hydrobiologia. 639:231-243.

Komárek J (2013). Cyanoprokaryota Part 3: Heterocystous genera. In: Büdel B, Gärtner G, Krienitz L et al., editors: Süsswasserflora von Mitteleuropa. Heidelberg: Springer Spektrum:1131.

Komárek J, Anagnostidis K (1986). Modern approach to the classification system of Cyanophytes. 2-Chroococcales. Arch Hydrobiol Suppl. 73:157-226.

Komárek J, Anagnostidis K (1989). Modern approach to the classification system of Cyanophytes 4-Nostocales. Arch Hydrobiol Suppl. 82:247-345.

Komárek J, Anagnostidis K (2007). Cyanoprokaryota Part 2: Oscillatoriales. In: Büdel B, Gärtner G, Krienitz L et al., editors: Süßwasserflora von Mitteleuropa Vol 19. Heidelberg: Springer Spektrum:759.

Komárek J, Anagnostidis K (2008) Cyanoprokaryota Part 1: Chroococcales. In: Ettl H, Gärtner G, Heynig H et al., editors: Süwasserflora von Mitteleuropa. Heidelberg: Springer Spektrum:548.

Komárek J, Cronberg G (2001). Some chroococcalean and oscillatorialean Cyanoprokaryotes from southern African lakes, ponds and pools. Nova Hedwigia:129-160.

Komárek J, Zapomělová E (2007). Planktic morphospecies of the cyanobacterial genus Anabaena= subg. Dolichospermum-1. part: coiled types. Fottea. $7: 1-31$.

Kremer CT, Gillette JP, Rudstam LG, Brettum P, Ptacnik R (2014). A compendium of cell and natural unit biovolumes for $>1200$ freshwater phytoplankton species. Ecology. 95:2984-2984.

Kurmayer R, Christiansen G (2009). The genetic basis of toxin production in cyanobacteria. Freshwater Rev. 2:31-50.

Kurmayer R, Christiansen G, Chorus I (2003). The abundance of microcystin-producing genotypes correlates positively with colony size in Microcystis sp. and determines its microcystin net production in Lake Wannsee. Appl Environ Microbiol. 69:787-795.

Kurmayer R, Dittmann E, Fastner J, Chorus I (2002). Diversity of microcystin genes within a population of the toxic cyanobacterium Microcystis spp. in Lake Wannsee (Berlin, Germany). Microb Ecol. 43:107-118.

Kurmayer R, Kutzenberger T (2003). Application of real-time PCR for quantification of microcystin genotypes in a population of the cyanobacterium Microcystis sp. Appl Environ Microbiol. 69:6723-6730.

Kurmayer R, Schober E, Tonk L, Visser PM, Christiansen G (2011). Spatial divergence in the proportions of genes encoding toxic peptide synthesis among populations of the cyanobacterium Planktothrix in European lakes. FEMS Microbiol Lett. 317:127-137.

Kurmayer R, Sivonen K, Wilmotte A, Salmaso N, editors (2017). Molecular tools for the detection and quantification of toxigenic cyanobacteria. Chichester: John Wiley \& Sons:392 pp.

Lee RE (2018). Phycology, fifth edition. Cambridge, UK: Cambridge University Press:546 pp. 
Lei L, Lei M, Lu Y, Peng L, Han B-P (2019). Development of real-time PCR for quantification of Cylindrospermopsis raciborskii cells and potential cylindrospermopsin-producing genotypes in subtropical reservoirs of southern China. J Appl Phycol. 31:3749-3758.

Lu K-Y, Chiu Y-T, Burch M, Senoro D, Lin T-F (2019). A molecular-based method to estimate the risk associated with cyanotoxins and odor compounds in drinking water sources. Water Res. 164:114938.

Lund J, Kipling C, Le Cren E (1958). The inverted microscope method of estimating algal numbers and the statistical basis of estimations by counting. Hydrobiologia. 11:143-170.

Ma S, Tao Z, Yang X, Yu Y, Zhou X, Li Z (2014). Bathymetry retrieval from hyperspectral remote sensing data in optical-shallow water. IEEE Trans Geosci Remote Sens. 52:1205-1212.

Mankiewicz-Boczek J, Kokociński M, Gagała I, Pawełczyk J, Jurczak T, Dziadek J (2012). Preliminary molecular identification of cylindrospermopsin-producing cyanobacteria in two Polish lakes (Central Europe). FEMS Microbiol Lett. 326:173-179.

Marce R, George G, Buscarinu P, Deidda M, Dunalska J, de Eyto E et al. (2016). Automatic high frequency monitoring for improved lake and reservoir management. Environ Sci Technol. 50:10780-10794.

Martins JC, Vasconcelos VM (2009). Microcystin dynamics in aquatic organisms. J Toxicol Environ Health Part B. 12:65-82.

Mazmouz R, Chapuis-Hugon F, Mann S, Pichon V, Méjean A, Ploux O (2010). Biosynthesis of cylindrospermopsin and 7-epicylindrospermopsin in Oscillatoria sp strain PCC 6506: identification of the cyr gene cluster and toxin analysis. Appl Environ Microbiol. 76:4943-4949.

McDonald D, Price MN, Goodrich J, Nawrocki EP, DeSantis TZ, Probst A et al. (2012) An improved Greengenes taxonomy with explicit ranks for ecological and evolutionary analyses of bacteria and archaea. ISME J. 6:610-618.

McQuaid N, Zamyadi A, Prévost M, Bird DF, Dorner S (2011). Use of in vivo phycocyanin fluorescence to monitor potential microcystin-producing cyanobacterial biovolume in a drinking water source. J Environ Monitor. 13:455-463.

Mejean A, Mann S, Vassiliadis G, Lombard B, Loew D, Ploux O (2009). In vitro reconstitution of the first steps of anatoxin-a biosynthesis in Oscillatoria PCC 6506: from free L-proline to acyl carrier protein bound dehydroproline. Biochemistry. 49:103-113.

Mihali TK, Kellmann R, Muenchhoff J, Barrow KD, Neilan BA (2008). Characterization of the gene cluster responsible for cylindrospermopsin biosynthesis. Appl Environ Microbiol. 74:716-722.

Moffitt MC, Neilan BA (2004). Characterization of the nodularin synthetase gene cluster and proposed theory of the evolution of cyanobacterial hepatotoxins. Appl Environ Microbiol. 70:6353-6362.

Montreuil A-L, Levoy F, Bretel P, Anthony EJ (2014). Morphological diversity and complex sediment recirculation on the ebb delta of a macrotidal inlet (Normandy, France): a multiple LiDAR dataset approach. Geomorphology. 219:114-125.

Moreira C, Vasconcelos V, Antunes A (2013). Phylogeny and biogeography of cyanobacteria and their produced toxins. Mar Drugs. 11:4350-4369. 
Murray SA, Diwan R, Orr RJ, Kohli GS, John U (2015). Gene duplication, loss and selection in the evolution of saxitoxin biosynthesis in alveolates. Mol Phylogen Evol. 92:165-180.

Murray SA, Mihali TK, Neilan BA (2011). Extraordinary conservation, gene loss, and positive selection in the evolution of an ancient neurotoxin. Mol Biol Evol. 28:1173-1182.

Napiórkowska-Krzebietke A, Kobos J (2016). Assessment of the cell biovolume of phytoplankton widespread in coastal and inland water bodies. Water Res. 104:532-546.

Neilan BA (1995). Identification and phylogenetic analysis of toxigenic cyanobacteria by multiplex randomly amplified polymorphic DNA PCR. Appl Environ Microbiol. 61:2286-2291.

Nishizawa T, Asayama M, Fujii K, Harada K-I, Shirai M (1999). Genetic analysis of the peptide synthetase genes for a cyclic heptapeptide microcystin in Microcystis spp. J Biochem. 126:520-529.

Nshimyimana JP, Cruz MC, Wuertz S, Thompson JR (2019). Variably improved microbial source tracking with digital droplet PCR. Water Res. 159:192-202.

Odate T, Hirawake T, Kudoh S, Klein B, LeBlanc B, Fukuchi M (2002). Temporal and spatial patterns in the surface-water biomass of phytoplankton in the North Water. Deep Sea Res, Part II. 49:4947-4958.

Okello W, Portmann C, Erhard M, Gademann K, Kurmayer R (2010). Occurrence of microcystin-producing cyanobacteria in Ugandan freshwater habitats. Environ Toxicol. 25:367-380.

Olenina I, Hajdu S, Edler L, Andersson A, Wasmund N, Busch S et al. (2006). Biovolumes and size-classes of phytoplankton in the Baltic Sea. Baltic Marine Environment Protection Commission: Proc. No. 106, Helsinki. 144 pp.

Orr RJ, Stüken A, Murray SA, Jakobsen KS (2013). Evolutionary acquisition and loss of saxitoxin biosynthesis in dinoflagellates: the second "core" gene, sxtG. Appl Environ Microbiol 79:2128-2136.

Ostermaier V, Christiansen G, Schanz F, Kurmayer R (2013). Genetic variability of microcystin biosynthesis genes in Planktothrix as elucidated from samples preserved by heat desiccation during three decades. PLoS One 8:e80177.

Ostermaier V, Kurmayer R (2009). Distribution and abundance of nontoxic mutants of cyanobacteria in lakes of the Alps. Microb Ecol. 58:323-333.

Ostermaier V, Kurmayer R (2010). Application of real-time PCR to estimate toxin production by the cyanobacterium Planktothrix sp. Appl Environ Microbiol. 76:3495-3502.

Otsuki A, Takamura N (1987). Comparison of chlorophyll-a concentrations measured by fluorometric HPLC and spectrophotometry methods in highly eutrophic shallow Lake Kasumigaura: With 5 figures in the text. Verh - Int Ver Theor Angew Limnol. 23:944-951.

Pacheco ABF, Guedes IA, Azevedo SM (2016). Is qPCR a reliable indicator of cyanotoxin risk in freshwater? Toxins. 8:172.

Padisák J, Adrian R (1999). Biovolumen und Biomasse. In: von Tümpling W, Friedrich G, editors: Methoden der biologischen Wasseruntersuchung 2 Biologische Gewässeruntersuchung. Jena: Gustav Fischer:334-368. 
Pessi IS, Maalouf PDC, Laughinghouse HD, Baurain D, Wilmotte A (2016). On the use of high-throughput sequencing for the study of cyanobacterial diversity in Antarctic aquatic mats. J Phycol 52:356-368.

Pinto A, von Sperling E, Moreira R (2001). Chlorophyll-a determination via continuous measurement of plankton fluorescence:: methodology development. Water Res. 35:3977-3981.

Ramberg L (1988). A simple method of quantifying filamentous algae in microscope. Swiss J Hydrol. 50:189-192.

Ramos V, Moreira C, Vasconcelos V (2017a). DNA extraction from food supplements SOP 5.6. In: Kurmayer R, Sivonen K, Wilmotte A et al., editors: Molecular tools for the detection and quantification of toxigenic cyanobacteria. Chichester: John Wiley \& Sons:153-156.

Ramos V, Moreira C, Vasconcelos V (2017b). PCR detection of microcystin biosynthesis genes from food supplements SOP 6.9. In: Kurmayer R, Sivonen K, Wilmotte A, Salmaso N, editors: Molecular Tools for the Detection and Quantification of Toxigenic Cyanobacteria. Chichester: John Wiley \& Sons:199-203.

Rantala-Ylinen A, Känä S, Wang H, Rouhiainen L, Wahlsten M, Rizzi E et al. (2011). Anatoxin-a synthetase gene cluster of the cyanobacterium Anabaena sp. strain 37 and molecular methods to detect potential producers. Appl Environ Microbiol. 77:7271-7278.

Rantala-Ylinen A, Savela H, Sivonen K, Kurmayer R (2017). Quantitative PCR. In: Kurmayer R, Sivonen K, Wilmotte a, Salmaso N, editors: Molecular tools for the detection and quantification of toxigenic cyanobacteria. Chichester: John Wiley \& Sons:205-210.

Rantala A, Fewer D, Hisbergues M, Rouhiainen L, Vaitomaa J, Börner T et al. (2004). Phylogenetic evidence for the early evolution of microcystin synthesis. Proc Natl Acad Sci USA. 101:568-573.

Rantala A, Rajaniemi-Wacklin P, Lyra C, Lepistö L, Rintala J, Mankiewicz-Boczek $\mathrm{J}$ et al. (2006). Detection of microcystin-producing cyanobacteria in Finnish lakes with genus-specific microcystin synthetase gene E (mcyE) PCR and associations with environmental factors. Appl Environ Microbiol. 72:6101-6110.

Rasmussen JP, Giglio S, Monis PT, Campbell RJ, Saint CP (2008). Development and field testing of a real-time PCR assay for cylindrospermopsin-producing cyanobacteria. J Appl Microbiol. 104:1503-1515.

Richards FA, Thompson TG (1952). The estimation and characterization of planktonic populations by pigment analysis. II. A spectrophotometric method for the estimation of plankton pigments. J Mar Res. 11:156-172.

Rinta-Kanto J, Ouellette A, Boyer G, Twiss M, Bridgeman T, Wilhelm S (2005). Quantification of toxic Microcystis spp. during the 2003 and 2004 blooms in western Lake Erie using quantitative real-time PCR. Environ Sci Technol. 39:4198-4205.

Ritchie RJ (2006). Consistent sets of spectrophotometric chlorophyll equations for acetone, methanol and ethanol solvents. Photosynth Res. 89:27-41.

Rott E (1981). Some results from phytoplankton counting intercalibrations. Aquat Sci. 43:34-62.

Rott E, Salmaso N, Hoehn E (2007). Quality control of Utermöhl-based phytoplankton counting and biovolume estimates-an easy task or a Gordian knot? Hydrobiologia. 578:141-146. 
Rouhiainen L, Vakkilainen T, Siemer BL, Buikema W, Haselkorn R, Sivonen K (2004). Genes coding for hepatotoxic heptapeptides (microcystins) in the cyanobacterium Anabaena strain 90. Appl Environ Microbiol. 70:686-692.

Rounge TB, Rohrlack T, Nederbragt AJ, Kristensen T, Jakobsen KS (2009). A genome-wide analysis of nonribosomal peptide synthetase gene clusters and their peptides in a Planktothrix rubescens strain. BMC Genomics. 10:396.

Rueckert A, Wood SA, Cary SC (2007). Development and field assessment of a quantitative PCR for the detection and enumeration of the noxious bloomformer Anabaena planktonica. Limnol Oceanogr Methods. 5:474-483.

Saccà A (2016). A simple yet accurate method for the estimation of the biovolume of planktonic microorganisms. PLoS One. 11:e0151955.

Saccà A (2017). Methods for the estimation of the biovolume of microorganisms: A critical review. Limnol Oceanogr Methods. 15:337-348.

Saker ML, Jungblut AD, Neilan BA, Rawn DFK, Vasconcelos VM (2005). Detection of microcystin synthetase genes in health food supplements containing the freshwater cyanobacterium Aphanizomenon flos-aquae. Toxicon. 46:555-562.

Saker ML, Welker M, Vasconcelos VM (2007). Multiplex PCR for the detection toxigenic cyanobacteria in dietary supplements produced for human consumption. Appl Microbiol Biotechnol. 73:1136-1142.

Salmaso N, Bernard C, Humbert JF, Akçaalan R, Albay M, Ballot A et al. (2017). Basic guide to detection and monitoring of potentially toxic cyanobacteria. In: Meriluoto J, Spoof L, Codd GA et al, editors: Handbook of cyanobacterial monitoring and cyanotoxin analysis. Chichester: John Wiley \& Sons. 46-69.

Sambrook J, Russell DW, editors (2001). Molecular cloning: a laboratory manual, third edition. Cold Spring Harbor (NY): Cold Spring Harbor Laboratory Press:2100 pp.

Sartory D, Grobbelaar J (1984). Extraction of chlorophyll a from freshwater phytoplankton for spectrophotometric analysis. Hydrobiologia 114:177-187.

Savela H, Harju K, Spoof L, Lindehoff E, Meriluoto J, Vehniäinen M et al. (2016). Quantity of the dinoflagellate sxtA4 gene and cell density correlates with paralytic shellfish toxin production in Alexandrium ostenfeldii blooms. Harmful Algae. 52:1-10.

Savela H, Spoof L, Perälä N, Preede M, Lamminmäki U, Nybom S et al. (2015). Detection of cyanobacterial sxt genes and paralytic shellfish toxins in freshwater lakes and brackish waters on Åland Islands, Finland. Harmful Algae. 46:1-10.

Sayers M, Fahnenstiel GL, Shuchman RA, Whitley M (2016). Cyanobacteria blooms in three eutrophic basins of the Great Lakes: a comparative analysis using satellite remote sensing. Int J Remote Sens. 37:4148-4171.

Schloss PD, Westcott SL, Ryabin T, Hall JR, Hartmann M, Hollister EB et al. (2009). Introducing mothur: open-source, platform-independent, community-supported software for describing and comparing microbial communities. Appl Environ Microbiol. 75:7537-7541.

Schober E, Werndl M, Laakso K, Korschineck I, Sivonen K, Kurmayer R (2007). Interlaboratory comparison of Taq Nuclease Assays for the quantification of the toxic cyanobacteria Microcystis sp. J Microbiol Meth. 69:122-128. 
Selmeczy GB, Tapolczai K, Casper P, Krienitz L, Padisák J (2016). Spatial-and niche segregation of DCM-forming cyanobacteria in Lake Stechlin (Germany). Hydrobiologia. 764:229-240.

Shih PM, Wu D, Latifi A, Axen SD, Fewer DP, Talla E et al. (2013). Improving the coverage of the cyanobacterial phylum using diversity-driven genome sequencing. Proc Natl Acad Sci USA. 110:1053-1058.

Silva T, Giani A, Figueredo C, Viana P, Khac VT, Lemaire BJ et al. (2016). Comparison of cyanobacteria monitoring methods in a tropical reservoir by in vivo and in situ spectrofluorometry. Ecol Eng. 97:79-87.

Sivonen K, Börner T (2008). Bioactive compounds produced by cyanobacteria. In: Herrero A, Flores E, editors: The cyanobacteria: molecular biology, genomics and evolution. Norfolk: Caister Academic Press:159-197.

Speziale BJ, Schreiner SP, Giammatteo PA, Schindler JE (1984). Comparison of $\mathrm{N}, \mathrm{N}$-dimethylformamide, dimethyl sulfoxide, and acetone for extraction of phytoplankton chlorophyll. Can J Fish Aquat Sci. 41:1519-1522.

Srivastava A, Singh S, Ahn C-Y, Oh H-M, Asthana RK (2013). Monitoring approaches for a toxic cyanobacterial bloom. Environ Sci Technol. 47:8999-9013.

Stich H, Brinker A (2005). Less is better: uncorrected versus pheopigment-corrected photometric chlorophyll-a estimation. Arch Hydrobiol. 162:111-120.

Strickland JD, Parsons TR (1972). A practical handbook of seawater analysis. Ottawa: Fisheries Research Board Canada.

Stucken K, John U, Cembella A, Murillo AA, Soto-Liebe K, Fuentes-Valdés JJ et al. (2010). The smallest known genomes of multicellular and toxic cyanobacteria: comparison, minimal gene sets for linked traits and the evolutionary implications. PLoS One. 5:e9235.

Stüken A, Jakobsen KS (2010). The cylindrospermopsin gene cluster of Aphanizomenon sp strain 10E6: organization and recombination. Microbiology. 156:2438-2451.

Sukenik A, Quesada A, Salmaso N (2015). Global expansion of toxic and nontoxic cyanobacteria: effect on ecosystem functioning. Biodivers Conserv. 24:889-908.

Taton A, Grubisic S, Brambilla E, De Wit R, Wilmotte A (2003). Cyanobacterial diversity in natural and artificial microbial mats of Lake Fryxell (McMurdo Dry Valleys, Antarctica): a morphological and molecular approach. Appl Environ Microbiol. 69:5157-5169.

Te SH, Chen EY, Gin KY-H (2015). Comparison of quantitative PCR and droplet digital PCR multiplex assays for two genera of bloom-forming cyanobacteria, Cylindrospermopsis and Microcystis. Appl Environ Microbiol. 81:5203-5211.

Tillett D, Dittmann E, Erhard M, von Döhren H, Börner T, Neilan BA (2000). Structural organization of microcystin biosynthesis in Microcystis aeruginosa PCC7806: an integrated peptide-polyketide synthetase system. Chem Biol. 7:753-764.

Tillett D, Neilan BA (2000). Xanthogenate nucleic acid isolation from cultured and environmental cyanobacteria. J Phycol. 36:251-258.

Utermöhl H (1958). Zur Vervollkommnung der quantitativen PhytoplanktonMethodik. Internationale Vereinigung für Theoretische und Angewandte Limnologie: Mitteilungen. 9:1-38. 
Vichi S, Lavorini P, Funari E, Scardala S, Testai E (2012). Contamination by Microcystis and microcystins of blue-green algae food supplements (BGAS) on the Italian market and possible risk for the exposed population. Food Chem Toxicol. 50:4493-4499.

Vuorio K, Lepistö L, Holopainen A-L (2007). Intercalibrations of freshwater phytoplankton analyses. Boreal Environ Res. 12:561-569.

Wang GQ, Lee ZP, Mishra DR, Ma RH (2016). Retrieving absorption coefficients of multiple phytoplankton pigments from hyperspectral remote sensing reflectance measured over cyanobacteria bloom waters. Limnol Oceanogr Methods. 14:432-447.

Wang S, Zhu L, Li Q, Li G, Li L, Song L et al. (2015). Distribution and population dynamics of potential anatoxin-a-producing cyanobacteria in Lake Dianchi, China. Harmful Algae. 48:63-68.

Wolanin A, Soppa MA, Bracher A (2016). Investigation of spectral band requirements for improving retrievals of phytoplankton functional types. Remote Sensing. 8:871.

Wood SA, Pochon X, Laroche O, von Ammon U, Adamson J, Zaiko A (2019). A comparison of droplet digital polymerase chain reaction (PCR), quantitative PCR and metabarcoding for species-specific detection in environmental DNA. Mol Ecol Res. 19:1407-1419.

Wood SA, Puddick J (2017). The abundance of toxic genotypes is a key contributor to anatoxin variability in Phormidium-dominated benthic mats. Marine Drugs. 15:307.

Xiao X, Sogge H, Lagesen K, Tooming-Klunderud A, Jakobsen KS, Rohrlack T (2014). Use of high throughput sequencing and light microscopy show contrasting results in a study of phytoplankton occurrence in a freshwater environment. PLoS One. 9:e106510.

Zamyadi A, Choo F, Newcombe G, Stuetz R, Henderson RK (2016). A review of monitoring technologies for real-time management of cyanobacteria: Recent advances and future direction. Trends Anal Chem. 85:83-96.

Zamyadi A, McQuaid N, Prévost M, Dorner S (2012). Monitoring of potentially toxic cyanobacteria using an online multi-probe in drinking water sources. J Environ Monitor. 14:579-588.

Zhu W, Tian YQ, Yu Q, Becker BL (2013). Using Hyperion imagery to monitor the spatial and temporal distribution of colored dissolved organic matter in estuarine and coastal regions. Remote Sens Environ. 134:342-354.

Zieger SE, Mistlberger Gn, Troi L, Lang A, Confalonieri F, Klimant I (2018). Compact and low-cost fluorescence based flow-through analyzer for earlystage classification of potentially toxic algae and in situ semiquantification. Environ Sci Technol. 52:7399-7408.

Ziegmann M, Abert M, Müller M, Frimmel FH (2010). Use of fluorescence fingerprints for the estimation of bloom formation and toxin production of Microcystis aeruginosa. Water Res. 44:195-204.

Zohary T, Shneor M, Hambright KD (2016). PlanktoMetrix - a computerized system to support microscope counts and measurements of plankton. Inland Waters. 6:131-135. 